\title{
Tentacle structure and filter-feeding in Crisia eburnea and other cyclostomatous bryozoans, with a review of upstream-collecting mechanisms
}

\author{
Claus Nielsen ${ }^{1, *}$, Hans Ulrik Riisgård ${ }^{2}$ \\ ${ }^{1}$ Zoological Museum (University of Copenhagen), Universitetsparken 15, DK-2100 Copenhagen, Denmark \\ ${ }^{2}$ Research Centre for Aquatic Biology (Institute of Biology, Odense University), Hindsholmvej 11, DK-5300 Kerteminde, Denmark
}

\begin{abstract}
The upstream-collecting filter-feeding mechanisms occurring in many aquatic organisms are not adequately described. Tentacles of Crisia eburnea and other cyclostome bryozoans, with only lateral and laterofrontal ciliary bands, are among the least complicated upstream-collecting systems among metazoans. SEM and TEM revealed that the tentacles have 2 rows of very closely set lateral cilia and 1 row of stiff laterofrontal cilia on each side. The shape of the basal membrane and the longitudinal muscles indicate that the tentacles are specialized for flicking movements directed towards the centre of the tentacle crown. Video observations of $C$. eburnea feeding on Rhodomonas cells showed characteristic velocity gradients around the tentacle crown. Particles in the central current gain the highest velocity at the entrance to the tentacle crown from where the speed decreases to zero in front of the mouth. Usually the path of a particle deviates from the downward course to a more outwards directed course (between the tentacies), where they may be trapped by lue filiè fưruled by the stiff lâterofiroñtâl cilia; the tentacle then makes a flick that brings the particle into the central current and further down towards the mouth. A survey of the literature shows that a similar mechanical filter mechanism occurs also in gymnolaemate bryozoans and their cyphonautes larvae, but that the particle-collecting mechanism of larvae and adults of phoronids, brachiopods, pterobranchs, and enteropneusts is different. The differences in structure and function between the tentacles of ectoprocts and those of phoronids, brachiopods and pterobranchs support the idea that the 2 types of tentacle crowns are not homologous.
\end{abstract}

KEY WORDS: Ectoproct feeding $\cdot$ Ciliary filter - Sieving $\cdot$ Bio-fluid-mechanics - Video observations Ultrastructure Phylogeny

\section{INTRODUCTION}

Ciliary filter-feeding mechanisms occur in many aquatic organisms. Strathmann et al. (1972) recognized 2 main types, opposed and single band systems, which were called downstream-collecting and upstreamcollecting bands, respectively, by Nielsen \& Rostgaard (1976). A thorough description of the various types of ciliary systems has extensive importance for the basic understanding of ciliary filter-feeding in aquatic invertebrates and of phylogenetic interrelationships of the bilaterian phyla. Superficially, the arrangement of cilia in ciliary bands may appear rather similar, but both

•E-mail: cnielsen@zmuc.ku.dk structure and function of the 2 systems are quite different and it seems impossible to bridge the gap between the 2 types of particle-collecting systems (Nielsen 1995, Nielsen et al. 1996).

In the downstream-collecting ciliary bands, compound cilia on multiciliate cells transfer particles from the water current in a not fully understood way (e.g. Shimeta \& Jumars 1991, Mayer 1994) to the downstream side of the band, where they are taken over by a band of separate cilia which transports the particles towards the mouth (Strathmann et al. 1972, Nielsen 1987). Downstream-collecting bands are characteristic of trochophora larvae of gastropods, bivalves, polychaetes, and entoprocts, and of adult sabellid polychaetes and some rotifers (e.g. Strathmann et al. 1972, Nielsen 1987, Gallager 1988). The mitraria larva of the 
polychaete Owenia has separate cilia on monociliate cells, but this is the only known exception among the downstream-collecting species.

In the upstream-collecting ciliary bands, separate cilia on mono- or multiciliate cells divert the particles from the main current and concentrate them on the upstream side of the band where they move towards the mouth. Upstream-collecting bands are found in larvae of ectoprocts, phoronids, brachiopods, echinoderms, and enteropneusts, and on the tentacles of adult ectoprocts, phoronids, brachiopods, and pterobranchs, and in the bivalve gill (Nielsen 1987). The mechanisms involved in separating food particles from the currents set up by the ciliary bands in upstreamcollecting organisms are poorly understood.

The feeding apparatus of adult ectoproct bryozoans consists of a ring of ciliated tentacles which form a funnel with the mouth at the centre of its base. Three types of ciliary rows may be found on the tentacles: lateral, frontal and laterofrontal rows. The lateral cilia, which are set on multiciliate cells, produce a water current passing outwards between the tentacles, which results in the formation of a central current directed straight down the tentacle crown towards the mouth with the more lateral parts of the current deviating out between the tentacles (Ryland 1976). The ciliation of the frontal cells of the tentacles varies widely in different groups, but their possible role in the feeding process is not well known.

The particle-capture mechanism in upstream-collecting phyla is not adequately described. Bullivant proposed that food particles become separated from the deflected water currents by an impingement mechanism (Bullivant 1968). This hypothesis was supported by Gilmour (1978), but rejected by most other authors because the food particles generally have the same specific gravity as the water (Strathmann 1973). Instead, Strathmann proposed that particles are captured by local reversal of the beat of the lateral cilia, which should transport the particles to the frontal side of the tentacle and then towards the mouth (Strathmann et al. 1972, Strathmann 1973, 1982, Strathmann \& McEdward 1986), and this hypothesis was supported for example by the observations of $\operatorname{Hart}(1991,1996)$.

It has been suggested that the single row of stiff laterofrontal cilia of ectoproct tentacles, about $20 \mu \mathrm{m}$ long at intervals of 3 to $5 \mu \mathrm{m}$ (Gordon 1974, Nielsen 1987), may affect particle capture as sensors by initiating tentacle flicking or reversal of the beat of lateral cilia, and/or act as a sieve which strains the suspended food particles (Bullivant 1968, Winston 1978). Strathmann \& McEdward (1986) reported that the laterofrontal cilia of the cyphonautes larva act as a sieve. Gordon et al. (1987) summarized the conflicting hypotheses concerning particle retention, but until recently no conclusive experimental studies have been carried out to verify the sieving theory. The prevailing view has been that particles are retained upstream from the lateral cilia by a local reversal of beat of the lateral cilia (Strathmann 1973, 1982, LaBarbera 1984, Hart 1996). However, the video observations of Riisgẳrd \& Manriquez (1997) on 15 species showed that when a particle deviated from the downward course (towards the mouth) to outwards (between the tentacles) it was stopped at the frontal side of a tentacle. The trapped particle was sometimes (in some species) seen to move steadily down the tentacle surface towards the mouth, possibly driven by the frontal cilia. But more frequently, a tentacle flicking pushed the particle towards the central current of the tentacle crown to be carried down towards the mouth. These observations support the hypothesis of a laterofrontal filter which strains the water while the central current, created by the special pump-design of the tentacle crown, and the action of flicking tentacles in co-operation clean the filter and transport the trapped particles toward the mouth. Further, the measured narticle-retentinn efficiency was found to support the assumption of a mechanical laterofrontal filter in the ectoprocts. This description of the particle capture process decisively departs from previous work as it does not involve a momentary reversal in the beat of lateral cilia as theorized by Strathmann $(1973,1982)$ and Strathmann et al. (1972). The importance of the frontal cilia for the transport has remained uncertain, but preliminary observations on Crisia eburnea and Heteropora magna (Nielsen 1987) indicate that cyclostomatous bryozoans lack frontal cilia. The simple cyclostome ciliary design with only 2 bands, viz. lateral and laterofrontal, makes this one of the least complicated upstream-collecting systems among metazoans. Therefore, we decided to perform a study on cyclostomes with the main emphasis on tentacle structure and video observations of the food particle capture and transport mechanism in the intact tentacle crown. Especially the suggested mechanical. laterofrontal filter and the tentacle flicking mechanism, perhaps triggered by the putative sensory laterofrontal cilia, appeared to be of considerable functional and phylogenetic interest.

\section{MATERIAL AND METHODS}

Crisia eburnea Linnaeus, 1758 was collected from red algae, depth about $17 \mathrm{~m}$. Grollegrund, Northern Øresund, Denmark, 1976 to 1978, from red algae from a tide pool at Menai Strait, Wales, UK, 1997, and from red algae, 12 to $15 \mathrm{~m}$. NW of Flatholmen, Gullmarsfjorden, Sweden, 1997. Material of the following species was collected from San Juan Islands, WA, USA: 
Heteropora magna O'Donoghue \& O'Donoghue, 1923 and Disporella hispida (Fleming, 1828), on stones, 15 to $20 \mathrm{~m}$, Lopez Pass, 1981; Plagioecia patina (Lamarck, 1816), Diplosolen obelia (Johnston, 1838) and Tubulipora sp., on stones and Sabellaria-tubes, about $70 \mathrm{~m}$, off Rock Point, Shaw Island, 1992.

Electron microscopy. The material of Crisia eburnea studied with transmission electron microscopy (TEM) was the same as that described in Nielsen \& Pedersen (1979). For scanning electron microscopy (SEM), tentacle crowns were dissected out, narcotized with $7.5 \%$ $\mathrm{MgCl}_{2}$ in distilled water, fixed in 1 to $2 \% \mathrm{OsO}_{4}$ in distilled water, dehydrated in an acetone series, and critical point dried.

Video observations. The feeding process in intact and undisturbed zooids was recorded using a video camera (Kappa CF 11/1) attached to an inversed microscope (Labovert FS), and a 50 half-frames $\mathrm{s}^{-1}$ video recorder (Panasonic NV-FS200 HQ). A few branches of erect Crisia eburnea colonies were placed on the bottom of a cylindrical observation chamber placed on the microscope. The seawater $\left(32 \% \mathrm{~S} ; 15^{\circ} \mathrm{C}\right)$ in the observation chamber contained algal particles ( $6 \mu \mathrm{m}$ diameter flagellates Rhodomonas sp.) at a concentration of 2800 cells ml ${ }^{-1}$ (checked by means of an electronic particle counter, Elzone $80 \mathrm{XY}$ ). Capture of particles and tentacle flickings were traced from their position in successive video frames. The movements were followed by mounting a transparent plastic sheet onto the video screen so that the tentacle contours as well as the position of suspended particles could be marked with a pen directly on the sheet, frame by frame. Video pictures could also be copied by means of a video graphic printer (Sony UP-860 CE).

\section{RESULTS}

\section{Structure of tentacles and mouth region in Crisia eburnea}

Crisia eburnea has 8 rather short tentacles (length in full grown polypides about $200 \mu \mathrm{m}$ ). When expanded, the tentacles form a funnel with a basal angle of about $70^{\circ}$ and an entrance diameter of 250 to $300 \mu \mathrm{m}$; the distal parts of the tentacles curve slightly outwards.

Each tentacle consists of a small number of cell types in a fixed pattern (Figs. 1 \& 2). The ectoderm comprises the following types: (1) a frontal row of cells with distal, probably mucous inclusions; (2) on each side a laterofrontal row of cells each with a laterofrontal cilium; (3) on each side a double row of lateral cells with longitudinal rows of lateral cilia; (4) 2 rows of abfrontal cells; (5) abfrontal sensory cells; (6) nerves situated at

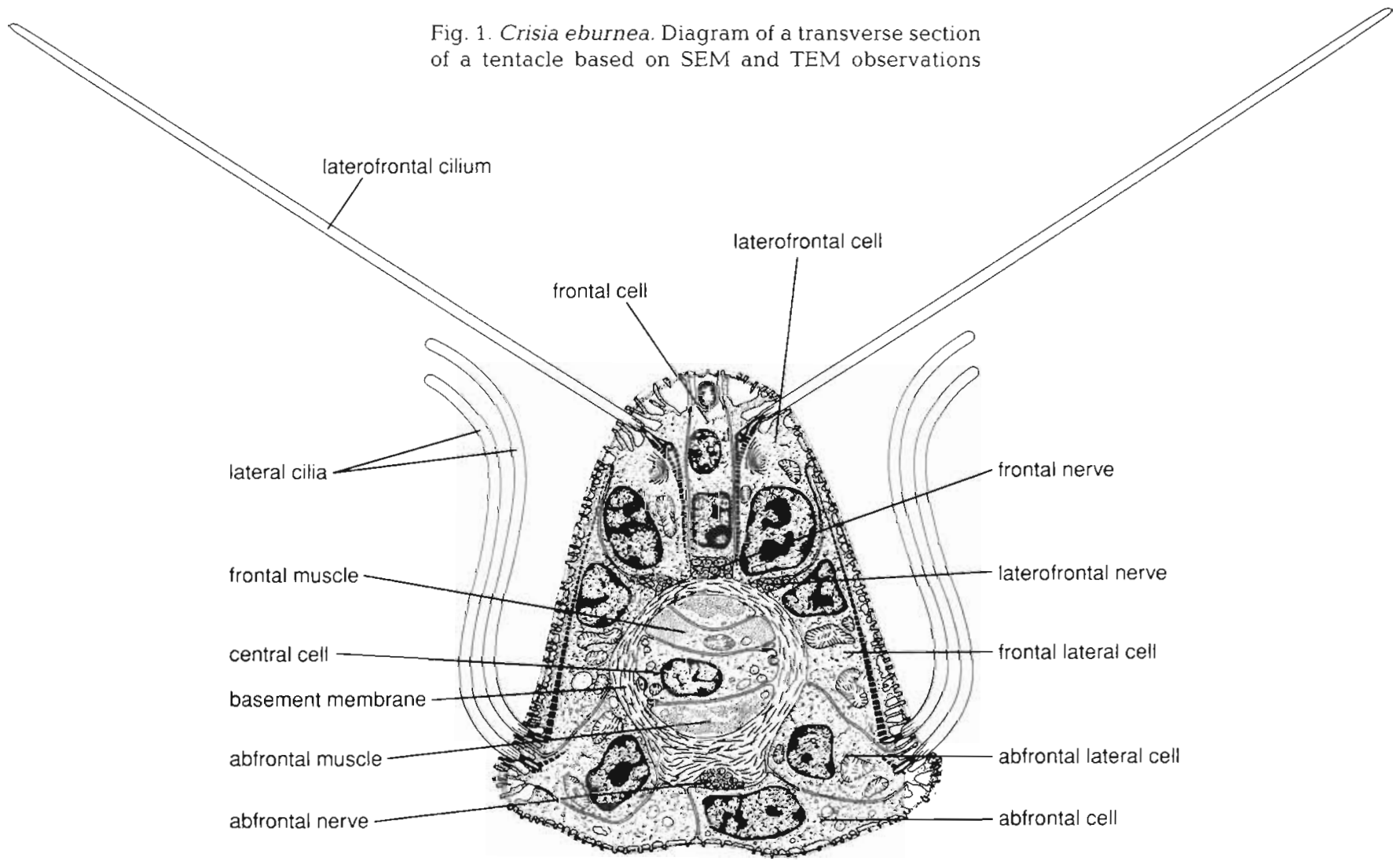




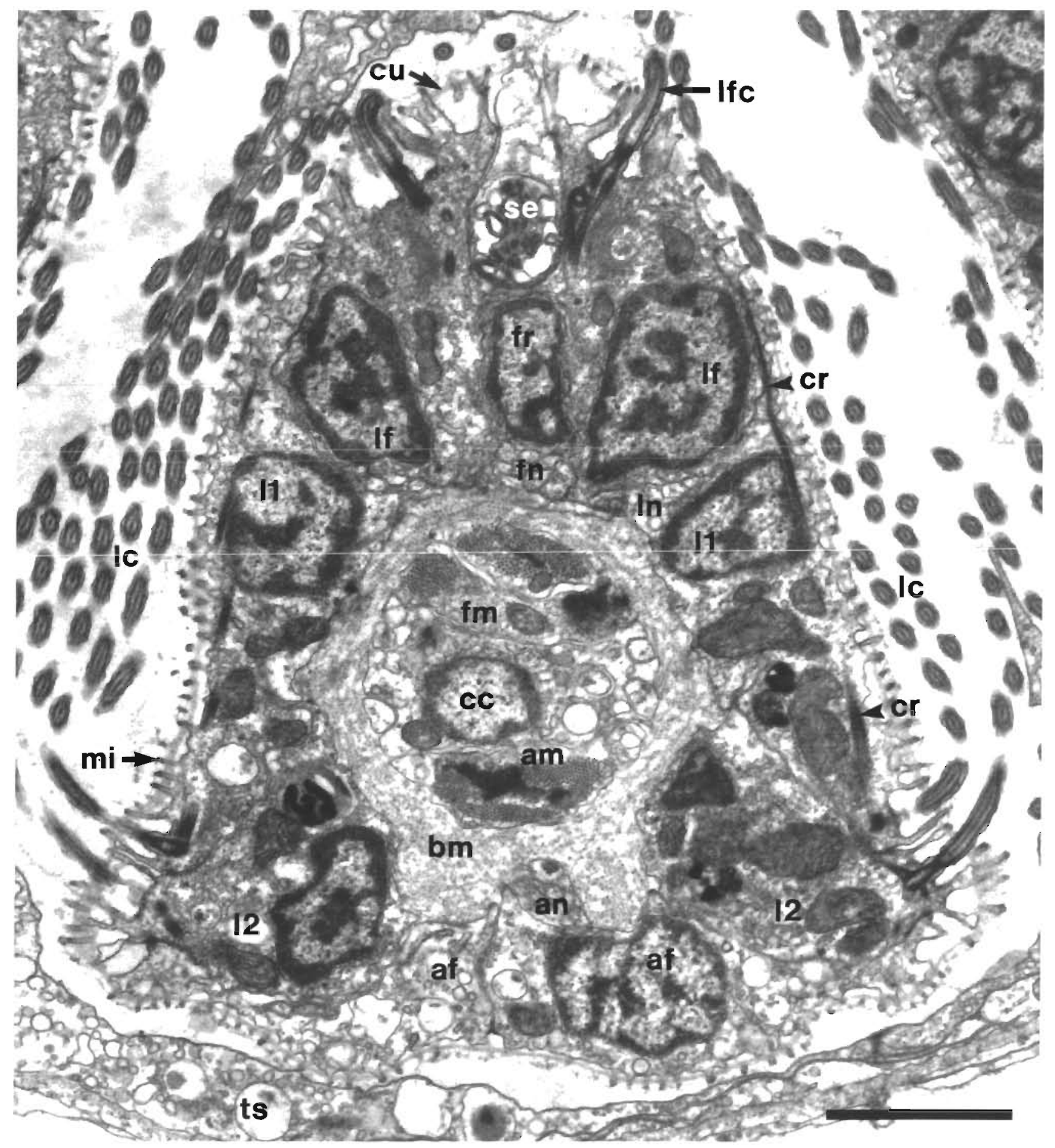

Fig 2 Crisla eburned. Transverse section of a tentacle; TEM af, abfrontal cell, am, abfrontal muscle; an, abfrontal nerve; bm, basement membrane; cc, central cell, cr, long ciliary rootlets of the frontal lateral cilia; cu, cuticle; fm, frontal muscle;

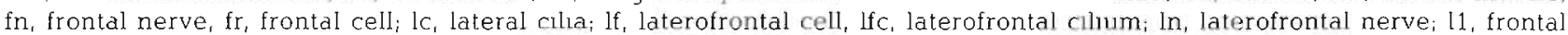
Iateral cell, 12. abfrontal lateral cell; mi, m.ıcrovilli; se, secretion in frontal cell, ts, tentacle sheath. Scale bar $=2 \mu \mathrm{m}$

the bases of the frontal, laterotrontal and abfrontal cells. All these cells rest on a thickened basement membrane, which surrounds mesodermal elements in the shape of a frontal and an abfrontal, longitudinal muscle and a row of central. cells. All the ectodermal cells have a surface with capped microvilli carrying a very thin electron-dense layer and with a more conspicuous layer at the middle level. 


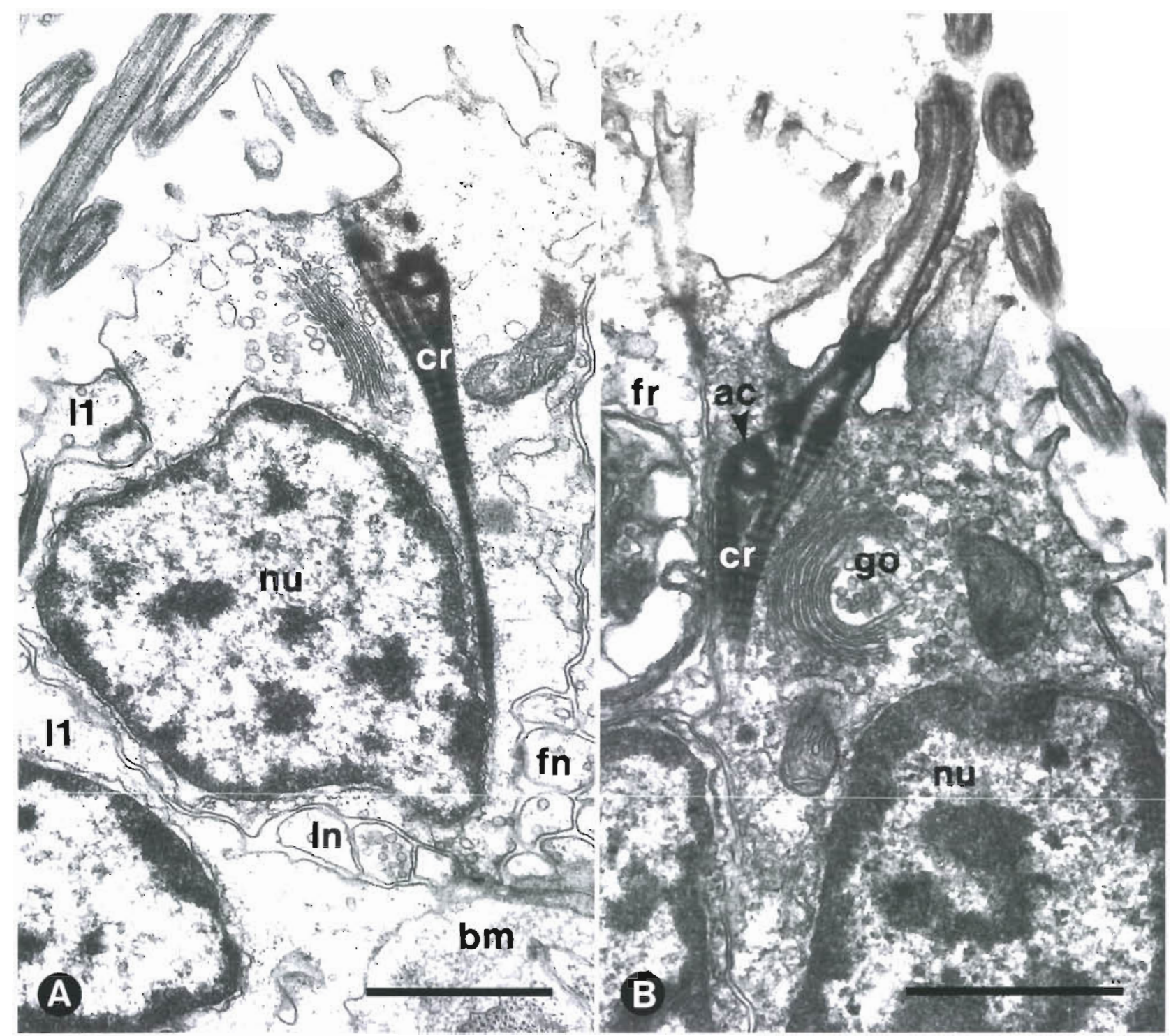

Fig. 3. Crisia eburnea. Laterofrontal cells in cross sections of tentacles, TEM. (A) Laterofiontal cell with the culiary root reachung almost to the base of the cell; note also the laterofrontal and lateral nerves. (B) Distal part of a laterofrontal cell showing the basal apparatus of the cilium. ac, accessory centriole, bm, basement membiane. cr, ciliary root; fn, frontal nerve; fr, frontal cell, go, Golgi apparatus; 1 , laterofrontal nerve. 11, frontal lateral cell, nu, nucleus of laterofrontal cell. Scale bars $=1 \mu \mathrm{m}$

Frontal cells (Figs 2 \& 9A). These cells are very elongate with a narrow apical zone with many inclusions resembling mucous secretions In general, these cells are without cilia, but 4 or 5 single clla have been observed on the basal part of the tentacle close to the mouth (Fig. 9A)

Laterofrontal cells (Figs. 2, 3 \& 9A) Almost isodlametric cells with a large nucleus, a conspicuous Golg1 complex and 1 cilium situated in a depression surrounded by a collar of microvilli. The cillum is about $20 \mu \mathrm{m}$ long (measured on video recordings, see below) and has a basal complex with an accessory centriole and a ciliary root extending along the median side of the nucleus to the narrow basal side of the cell, possibly attaching to the basal cell membrane. The laterofrontal cilia form a straight row with the distance between cilla varying between 3 and $4 \mu \mathrm{m}$ (Fig. 9A); only near the base of the tentacle do the laterofrontal cells become shorter than they are wide and a tendency to a zigzag arrangement of the clla with a distance of 2 to $3 \mu \mathrm{m}$ between the clla is observed (Fig. 9A). The basal part of the cells often contain small vesicles resembling those found in the neighbouring nerve fibres, but synapses have not been observed.

Lateral cells (Figs. 2 \& 5). The lateral cells form 2 rows, a frontal and an abfrontal row; they are rather 


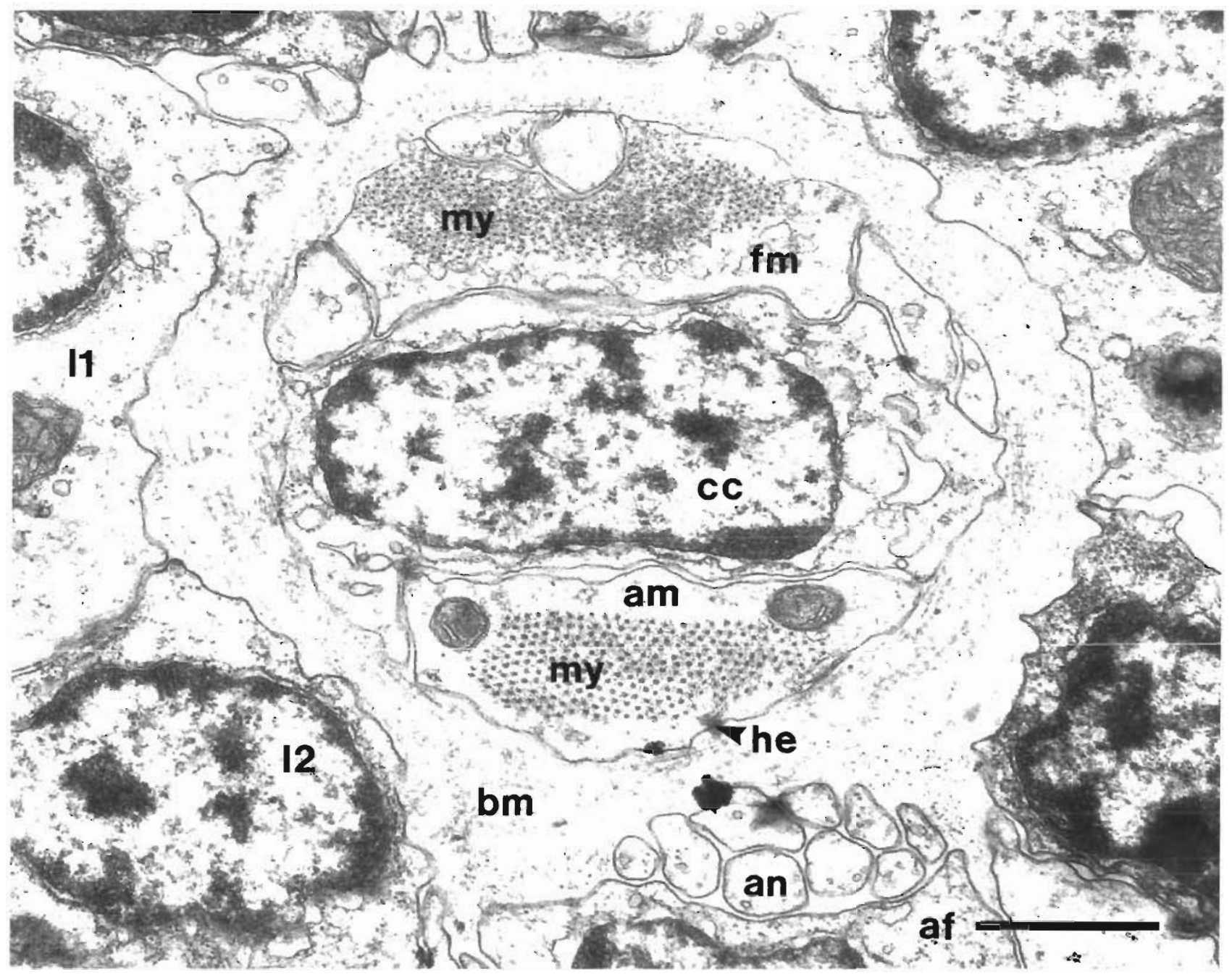

Fig 4 Crisla eburnea Transverse section of the central part of a tentacle, TEM. Central cell and longitudinal muscles surrounded by thickened basement membrane, which shows 'chicken-wire pattern' af, abfrontal cell; am, abfrontal longitudinal muscle; an, abfrontal nerve, bm, basement membrane; cc, central cell, fm, frontal longitudinal muscle; he, hemidesmosome; 11 , frontal Iateral cell, 12, abfrontal lateral cell. my, myofilaments Scale bar $=1 \mu \mathrm{m}$

elongate, about twice as long as the laterofrontal cells. The cells of the 2 rows are of quite different shapes: the frontal lateral cells cover the larger part of the lateral sides of the tentacles, including the lateral parts of the laterofrontal cells, whereas the abfrontal cells have a narrow surface. Both types have a longitudinal row of 21 to 25 very closely set clla with a length of 15 to $20 \mu \mathrm{m}$; the space between nelghbourng cllia in a row is only about $0.05 \mu \mathrm{m}$ and the distance between the 2 parallel rows is about $2 \mu \mathrm{m}$ The cllia of the frontal cell row have very long stnated rootlets extending all the way through the thın, trontal part of the cells The cilia of the abfrontal row have short rootlets and small feet.

Abirontal cells (Figs. $2 \& 9 B$ ) The abfrontal surface of the tentacles is covered by 2 rows of elongate cells The nuclei of the 2 rows of cells are arranged in an alternating pattern, so that usually a large cell with a nucleus and a small cell without nucleus are seen in transverse sections

Abfrontal sense organs (Fig. 9B). The basal part of each tentacle shows a median row of 4 to 5 cells without cilia, and this row continues along the tentacle in a series of scattered, putative sensory cells with a narrow, elongate apical surface with a cilium.

Nerves (Figs $2 \& 4$ ). There are 4 longitudinal nerves in each tentacle a frontal nerve along the bases of the frontal cells, a paur of laterofrontal nerves along the bases of the laterofrontal cells and an abfrontal nerve in the groove between the abfrontal longitudinal ridges of the basement membrane. Each nerve consists of a few (usually 2 to 10 ) axons with a few ring-shaped structures, which may be synaptic vesicles or cross 


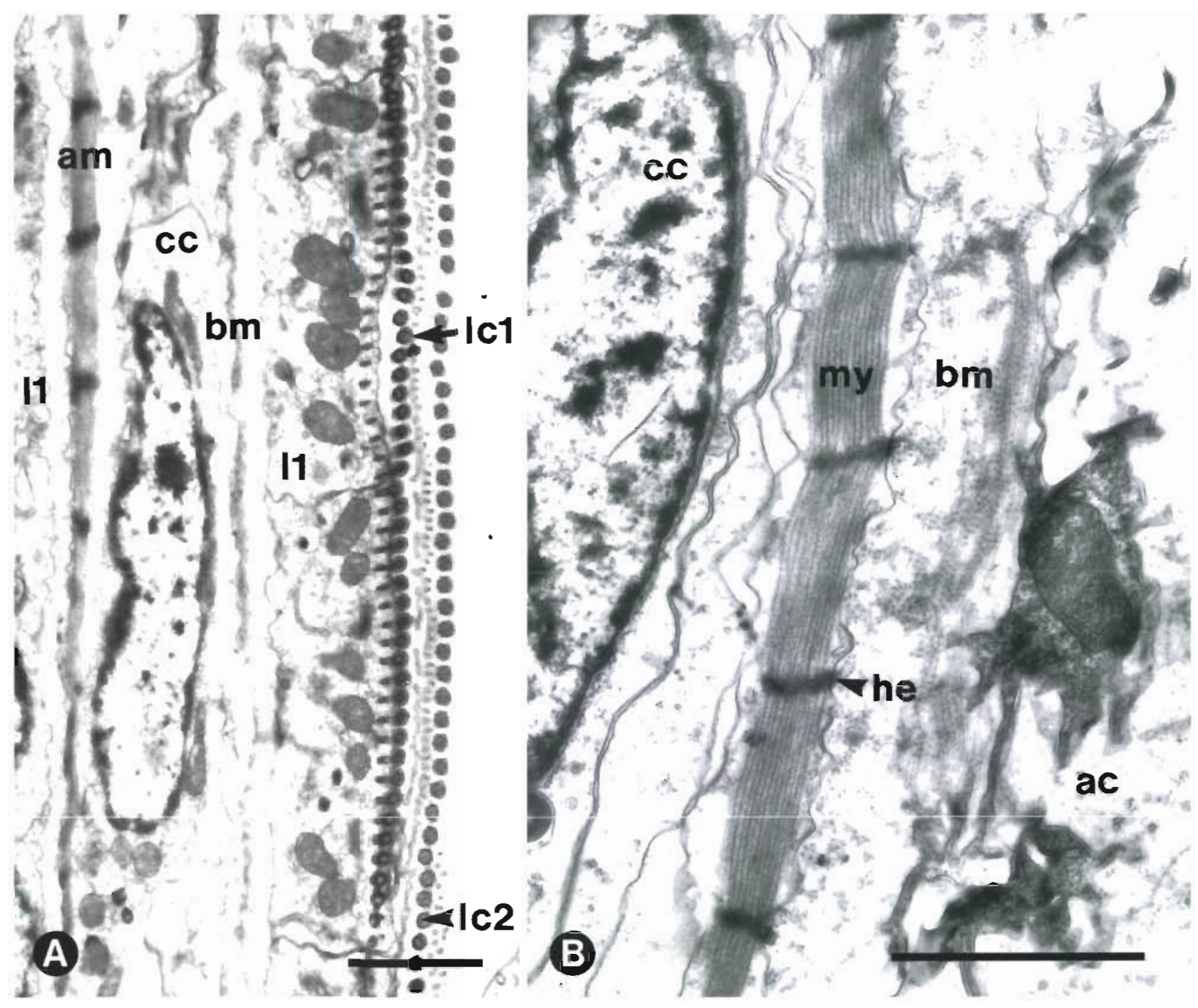

Fig. 5. Crisia eburnea. Longitudinal sections of tentacles; TEM. (A) Two frontal lateral cells with 23 and 24 cilia, respectively. (B) Abfrontal longitudinal muscle attached to the basement membrane with hemidesmosomes. ac, abfrontal cell; am, abfrontal

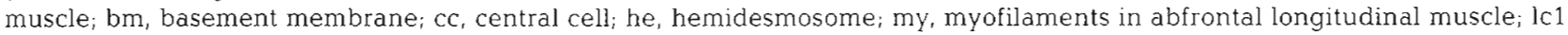
cilia of the frontal lateral cells; lc2, cilia of the frontal lateral cells; 11 , frontal longitudinal muscle. Scale bars $=2 \mu m$

sections of neurotubules. The laterofrontal nerves are probably the nerves of the laterofrontal cells, which show similar inclusions in the basal zone. The frontal and abfrontal nerves are probably motory, innervating the longitudinal muscles of the tentacle, but connections between the nerves and the muscle cells have not been observed. The abfrontal nerve probably also contains axons from the abfrontal sense cells.

Basement membrane (Figs. 4 \& 6). The rather thick basement membrane of the tentacles has the shape of a cylinder with a pair of latero-abfrontal ridges. At the base of the tentacles, the abfrontal parts of the tubes fuse into a thickened collar surrounding the mouth and forming the attachment both for the buccal dilator muscles and for the retractor muscles of the tentacle crown. The fixation used reveals the characteristic 'chicken-wire structure' characteristic of filaments of collagen IV. Isolated narcotized and dead tentacle crowns maintain a shape resembling that of the normal feeding zooid, and it appears that the flexible basement membrane passively returns to this shape.

Longitudinal muscles (Figs. 2, 4 \& 5). There are 2 longitudinal mesodermal muscles in each tentacle, 1 on the frontal and 1 on the abfrontal side. Each muscle consists of 1 to a few striated muscle cells. The Z-plates are attached to the basement membrane with hemidesmosomes. Contraction of the frontal muscle will bend the tentacle towards the centre of the tentacle crown. 

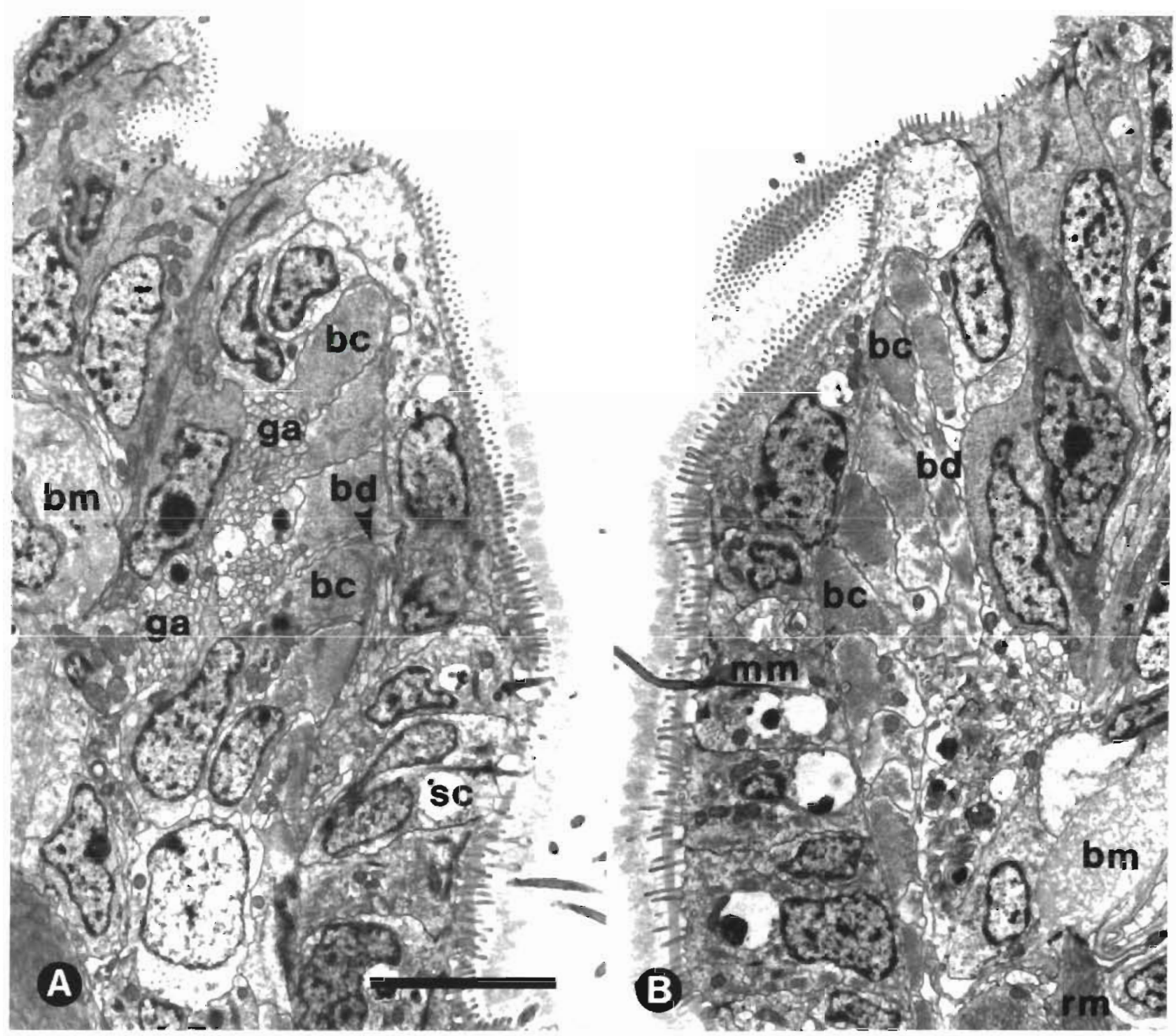

Fig, 6. Crisia eburnea. Two details of a longitudinal section of the mouth region; TEM. (A) The side close to the anus, showing the ganglion. (B) The side away from the anus. bc, buccal constrictor muscle; bd, branched buccal dilator muscle (magnified in Fig. $7 \mathrm{~B}$ ); bm, basement membrane at the base of the tentacles: ga, ganglion; $\mathrm{mm}$, multiciliate myoepithelial cell (magnified in

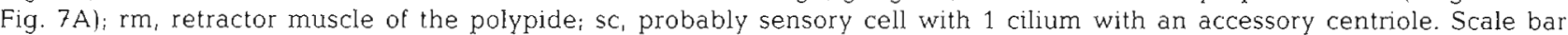
for both photos $=5 \mu \mathrm{m}$

Central cells (Figs. 2, 4 \& 5). A line of very elongate cells with rather electron-lucent cytoplasm with vesicles of varying sizes in the lateral parts occupies the central part of the tentacle. A few small cellular elements of unknown significance are found lateral to the central cells; they are larger and more irregular than the axons in the 4 longitudinal nerves.

Mouth region and pharynx (Figs. $6,7 \& 8$ ). The ectodermal cells of the region around the circular mouth and in the short buccal tube shows no cilia. The buccal tube is surrounded by 4 to 6 mesodermal, annular muscle cells forming the mouth constrictor, which is in close contact with the basement membrane. A number of radiating muscle cells are the mouth dilators; they originate at the collar-shaped thickened basement membrane surrounding the mouth and extend between the constrictor muscle cells to the basement membrane of the buccal tube. Both constrictor and dilator muscles are striated. The uppermost, short, tubular part of the pharynx shows ciliated cells of 2 types: monociliate, probably sensory, cells with the cilium situated in a depression and with an accessory centriole (Fig. 6A), and multiciliate cells without accessory centrioles and with striated myofilaments (Fig. 7A). The main part of the 


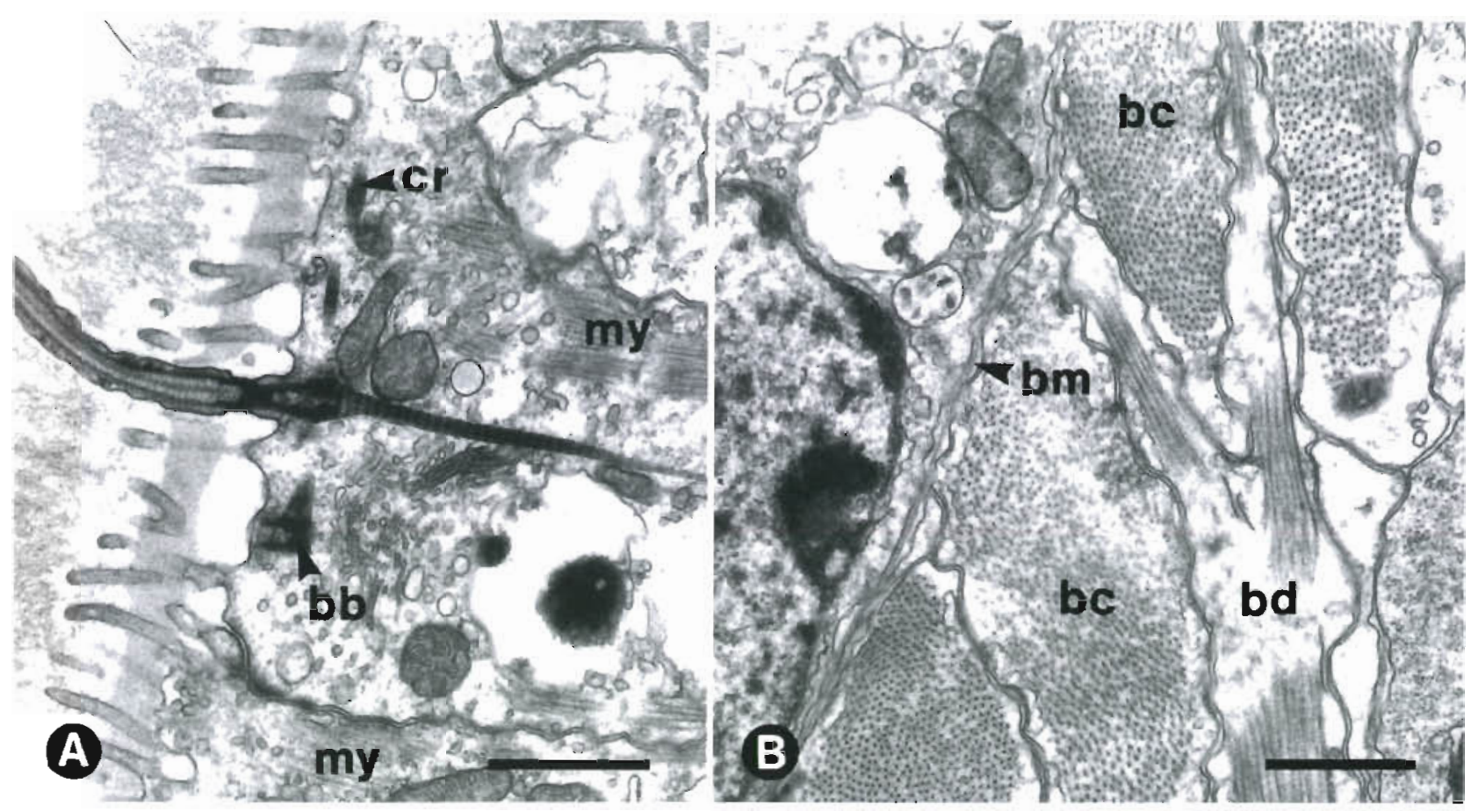

Fig. 7. Crisia eburnea. Longitudinal sections of the mouth region, details of cells shown in Fig. 6 ; TEM. (A) Multiciliate myoepithelial cell. (B) Detail of branched cell of the mouth dilator muscle. bb, basal body of cilium; bc, buccal constrictor muscle; bd, buccal dilator muscle; bm, basement membrane; cr, ciliary rootlet; my, myofilaments. Scale bars $=1 \mu \mathrm{m}$

pharyinx is triradiate consisting of striated myocpithelial cells (Fig. 8). It is surrounded by a thin layer of annular, mesodermal muscle cells, and a few thin, longitudinal muscle cells are found on the exterior side of the annular muscles; cilia and vacuoles have not been observed.

\section{Ciliary bands in other cyclostomes}

Tentacle structure of Disporella hispida, Plagioecia patina, Diplosolen obelia (Fig. 10A), Tubulipora sp. (Fig. 10B), and Heteropora magna (Fig. 11) was studied with the scanning electron microscope. All 5 species showed structures similar to those of Crisia eburnea, as decribed above. Frontal cilia were not observed in any of the species, and the arrangement of the lateral cilia was identical to that of C. eburnea. H. magna had larger tentacles, and the scanning micrographs indicate a higher number of abfrontal cells than in $C$. eburnea. Distances between laterofrontal cilia and their lengths could be measured in a number of cases, but whereas the distances are probably quite accurate, the lengths must be taken as minimum values because of the difficulties involved in measuring 3-dimensional structures on the micrographs. H. magna: distance 3 to $4 \mu \mathrm{m}$, length $13 \mu \mathrm{m} ; P$. patina: distance 2.5 to $3 \mu \mathrm{m}$, length 9 $\mu \mathrm{m} ; D$. obelia: distance 2.5 to $3 \mu \mathrm{m}$, length $9 \mu \mathrm{m}$; Tubulipora sp.: distance $3 \mu \mathrm{m}$, length $10 \mu \mathrm{m}$.

\section{Video observations of feeding in Crisia eburnea}

The flow pattern around the tentacle crown of an undisturbed Crisia eburnea feeding on Rhodomonas shows characteristic velocity gradients (Fig. 12). Particles in the narrow central current may be carried directly to the mouth, and these particles gain the highest velocity $\left(2.1 \mathrm{~mm} \mathrm{~s}^{-1}\right)$ at the entrance to the tentacle crown from where the speed decreases to zero just in front of the mouth. Usually the path of a particle entering the tentacle crown deviates from the downward course to a more outwards directed course (between the tentacles), where they may contact the laterofrontal ciliary filter on a tentacle which then makes a flick bringing the particle into the central current.

The tentacles may react to particle contact in different ways, here called 'individual' and 'collective' tentacle flicking (Fig. 13). Individual flicking is elicited when a single particle becomes trapped on the laterofrontal cilia on the distal part of a tentacle. The flicking usually brings the particle into the central current and thus downwards in the direction of the mouth (Fig. 12A). When a particle is approaching the tentacle crown closer to the central current, it will be trapped by the laterofrontal cilia of the more proximal part of 1 or 2 tentacles, and this elicits collective flicking, which usually involves 3 to 4 of the nearest tentacles 


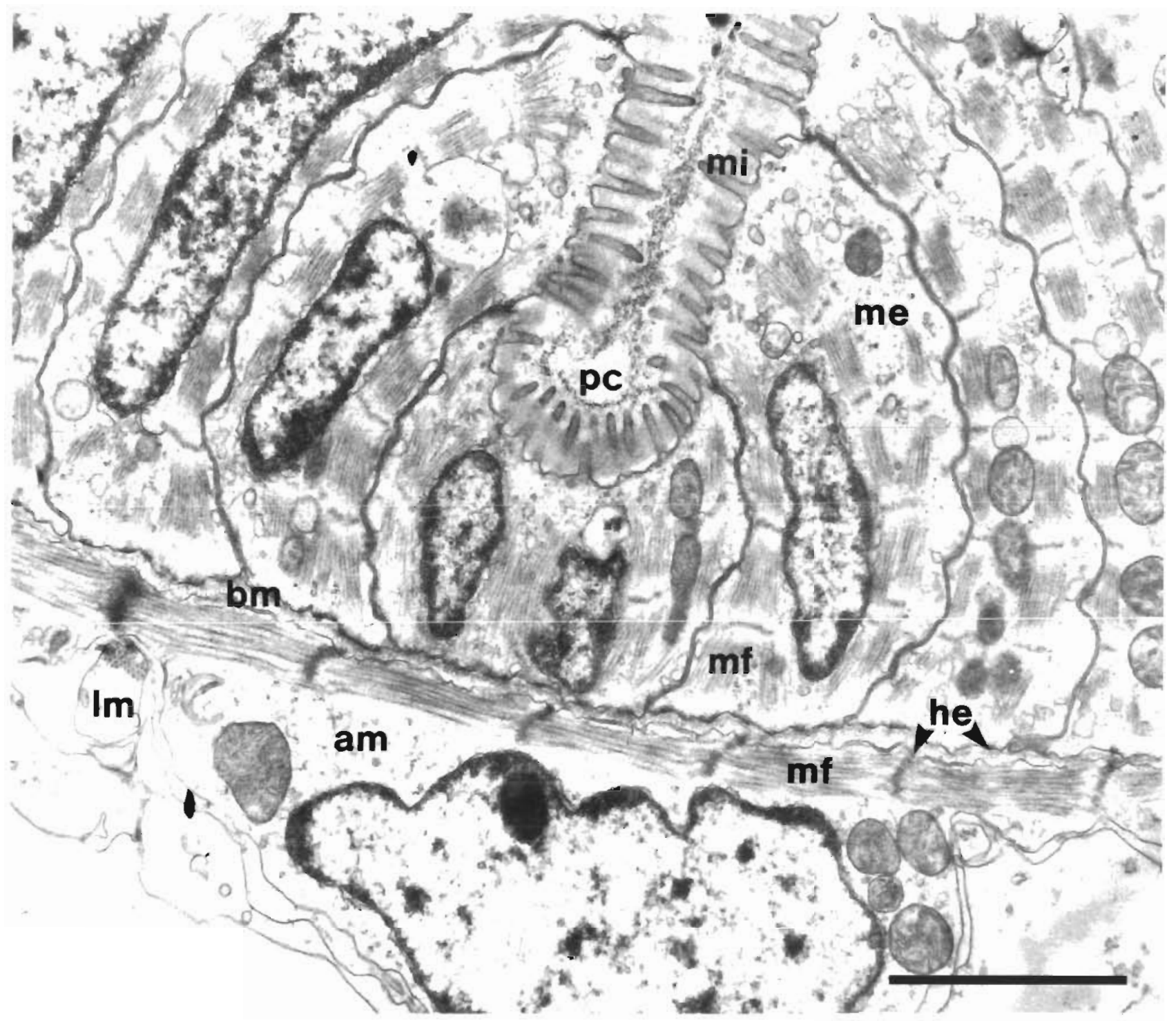

Fig 8 Crisia eburnea Transverse section of a part of the pharynx, TEM am, annular, mesodermal muscle cell surrounding the pharynx. bm. basement membrane, he, hemidesmosomes; Im, a small longitudinal muscle; me, myoepithelial. celli mf, myofilaments, mi, microvillı with electron dense layer, $p c$, pharyngeal cleft. Scale bar $=2 \mu \mathrm{m}$

(Figs 13B \& 14) In some cases the collective flicking involves the whole tentacle crown. The vast majority of particles are captured by either individual or collective flicking triggered by a single particle. The reaction of the tentacle to the particle is so rapid that the speed of the video recordings cannot resolve the detalls When a particle becomes trapped, the tentacles initiate flicking within less than $0.02 \mathrm{~s}$ bnnging the particle out of focus (Flg. 14). The treatment of trapped particles (1.e. the downwards transport) is thus based on individualized flicking, and there is therefore a close correlation between flicking frequency and particle concentration In our observations, the tentacle with the captured particle is out of focus in the position where the particle becomes transferred to the central current It is possible that the beat of the lateral cilia changes at this point to release the particle from the filter, but we could not observe it. However, such a mechanism seems unnecessary because the flow speed of the central current is up to 5 times higher than that through the laterofrontal filter (see below, 'The ectoproct filterpump'). When the tentacle bends inwards, the central current may simply drag the particle from the filter.

Normal particle capture does not involve transport along the frontal side of the tentacle, and in a rare instance in which a particle was trapped in the proximal part of the tentacle crown without immediately triggering a tentacle flick there was no change in the 

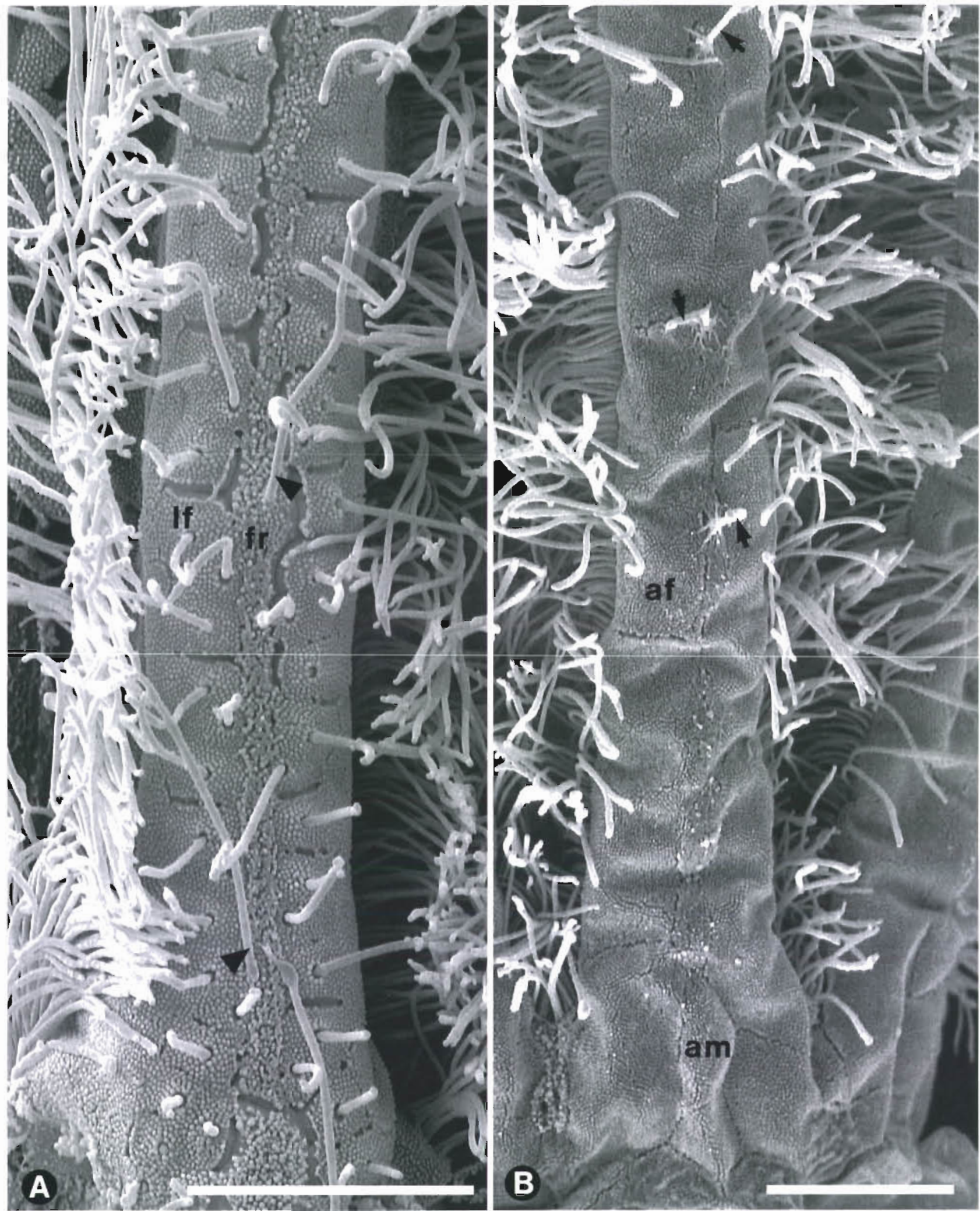

Fig. 9. Crisia eburnea, SEM of tentacles; the cuticle is slightly shrunk in most areas revealing the borders between the cells. (A) Frontal view of the proximal part of a tentacle. (B) Abfrontal view of proximal part of a tentacle. af, abfrontal cell; am, cell in the median abfrontal row; fr, frontal cell; lf, laterofrontal cell. Arrowheads: cilia of frontal cells; arrows point at cilia of the abfrontal sensory cells. Scale bars $=10 \mu \mathrm{m}$ 

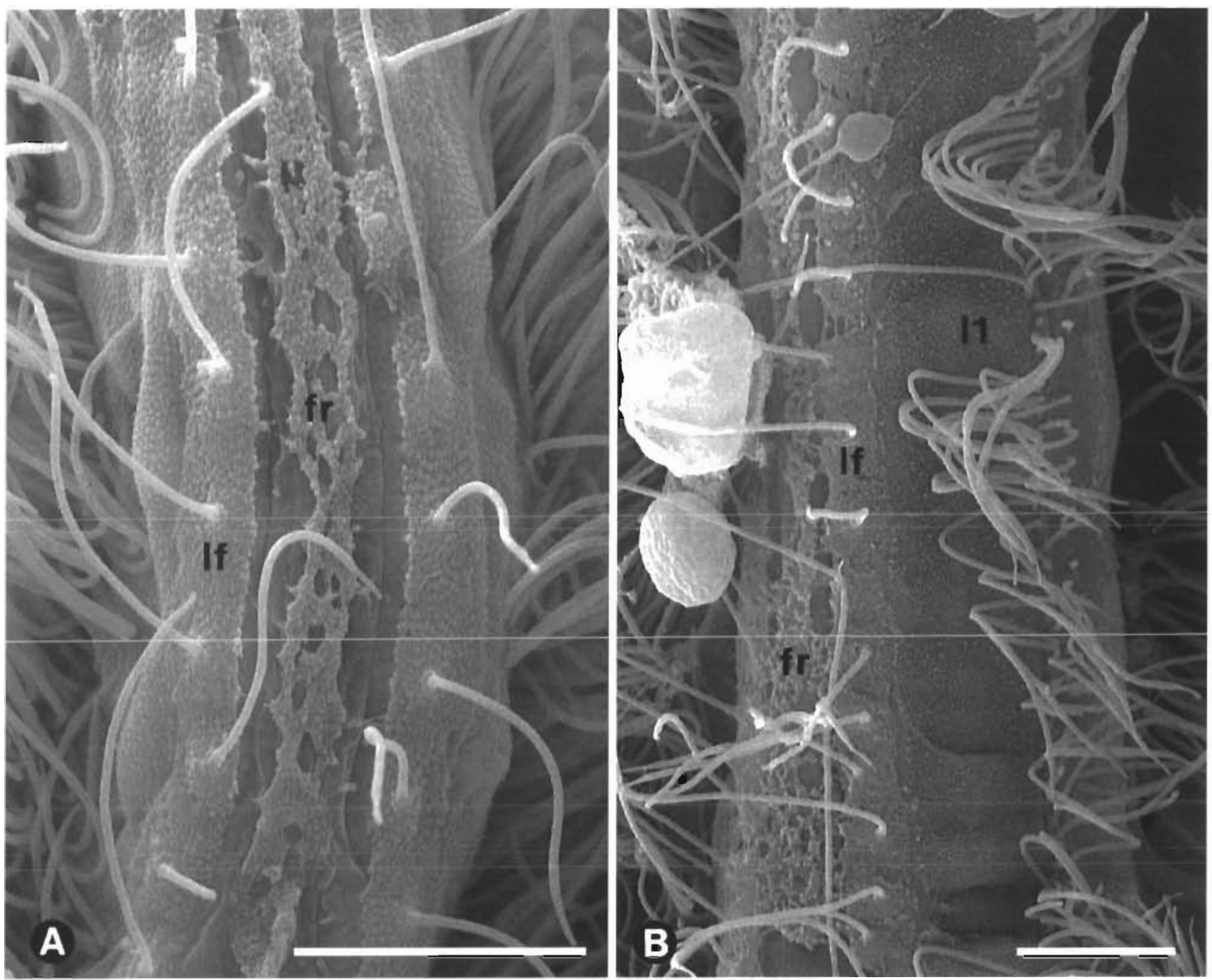

Fig 10. Scanning micrographs of tentacles. (A) Diplosolen obelia: frontal view of tentacle. (B) Tubulipora sp.; laterofrontal view

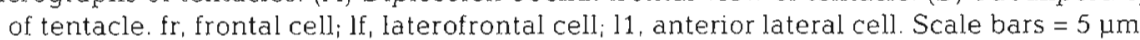

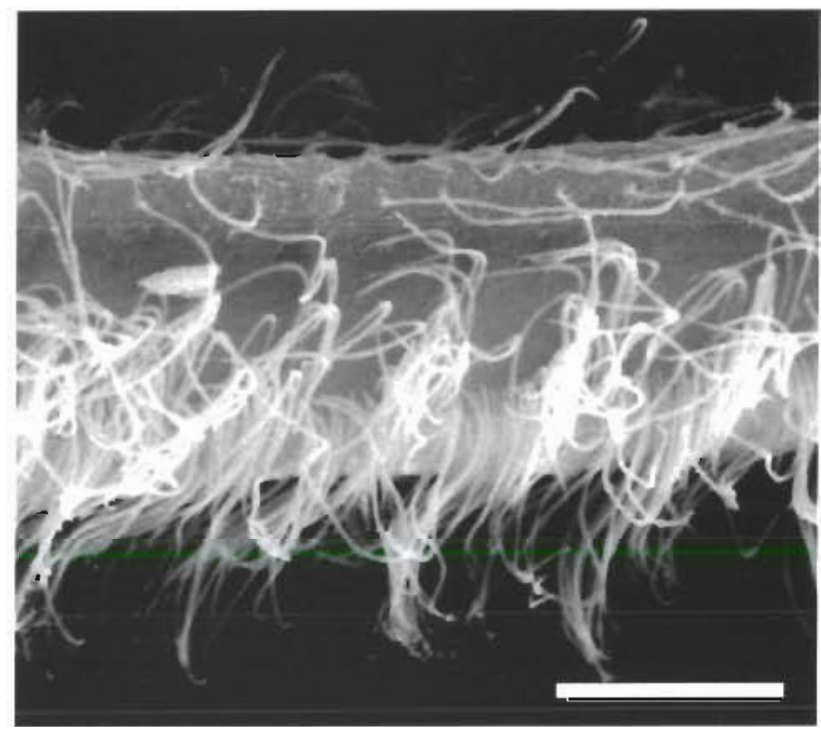

shape or speed of the metachronal waves along the lateral ciliary bands (Fig, 15). The tentacle is seen from the frontal side and the dexioplectic metachronal waves run anti-clockwise with a speed of $c=0.2 \mathrm{~mm}$ $\mathrm{s}^{-1}$ and a wavelength of $\lambda \approx 8 \mu \mathrm{m}$, and this pattern (with a beat frequency of the lateral cilia $f=c / \lambda=25 \mathrm{~Hz}$ ) was unaltered during $0.32 \mathrm{~s}$ (16 video frames) until the particle was finally pushed into the central current.

The video observations frequently showed every third laterofrontal cilium in focus with the 2 intervening cilia more or less blurred. This indicates that the laterofrontal cilia are not forming a flat comb of com-

Fig. 11. Heteropora magna, SEM. Lateral view of tentacle showing metachronal waves in the lateral ciliary band. Scale bar $=10 \mu \mathrm{m}$ 

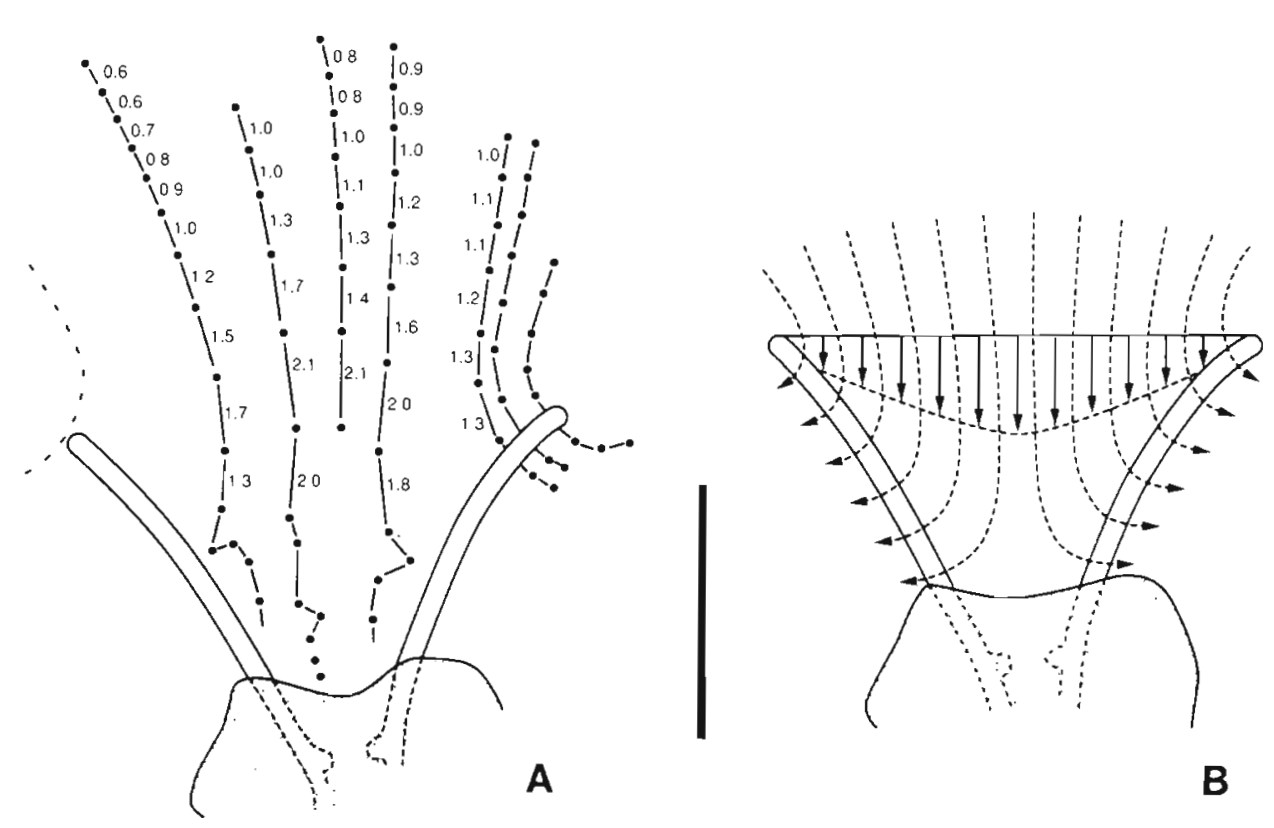

Fig. 12. Crisia eburnea. Flow pattern in the region of the tentacle crown obtained by means of video recording. (A) Flow lines and velocities of particles $\left(\mathrm{mm} \mathrm{s}^{-1}\right.$, based on a time interval of $0.02 \mathrm{~s}$ between subsequent video frames) are indicated. (B) Sketch of flow pattern (dotted lines) through the tentacle crown and velocity distribution of particles (arrows) in the entrance region where the maximum velocities of the incoming particles occur. Scale bar $=100 \mu \mathrm{m}$

pletely parallel cilia, but rather a band of rather stiff cilia which undulates somewhat at the tips of the cilia. This must result in a slightly larger distance between the tips of the laterofrontal cilia than between their bases, but not so much that the 'pore size' of the filter becomes much largor.

\section{DISCUSSION}

\section{Tentacle structure in ectoprocts}

Early studies, such as those of Borg (1926) and Atkins (1932), provided general information about the structure of the tentacles and the function of their cil- iary bands in several ectoprocts, including a number of cyclostomes. However, several structural details could not be resolved with the light microscope and understanding of the filtering mechanism required more detailed observations.

Transmission and scanning electron microscopical studies of ectoproct tentacles are scarce. Sections of gymnolaemate tentacles were described in detail by Lutaud (1973: Electra pilosa), Smith (1973: Flustrellidra hispida) and Gordon (1974: Cryptosula pallasiana), and scanning electron micrographs have been provided by Strathmann (1973: Membranipora sp.) and Gilmour (1978: Membranipora sp.). Mukai et al. (1997) described the lophophore of the phylactolaemate Pectinatella (Asajirella) gelatinosa. Gilmour (1978)
Fig. 13. Crisia eburnea. Sketches of 'individual' and 'collective' tentacle flicking, based on video pictures $(0.02 \mathrm{~s}$ between subsequent video frames). Scale bar $=100 \mu \mathrm{m}$. (A) Illustration of individual flicking caused by a single particle capture on the distal part of a tentacle. The particle is trapped by the laterofrontal ciliary filter, and this provokes immediately $(<0.02$ s) a single individual tentacle flick which brings the particle into the central current and thus downwards in the direction of the mouth. (B) A particle entering the funnel close to the central current is trapped on the frontal side of the proximal part of a tentacle, and this triggers collective flicking of 3 or 4 of the nearest tentacles

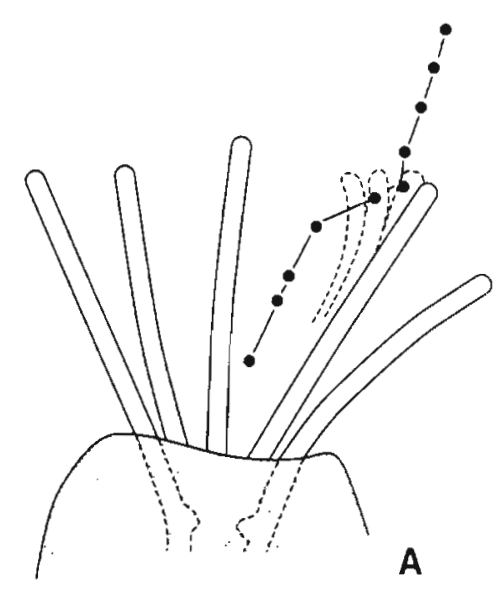

A

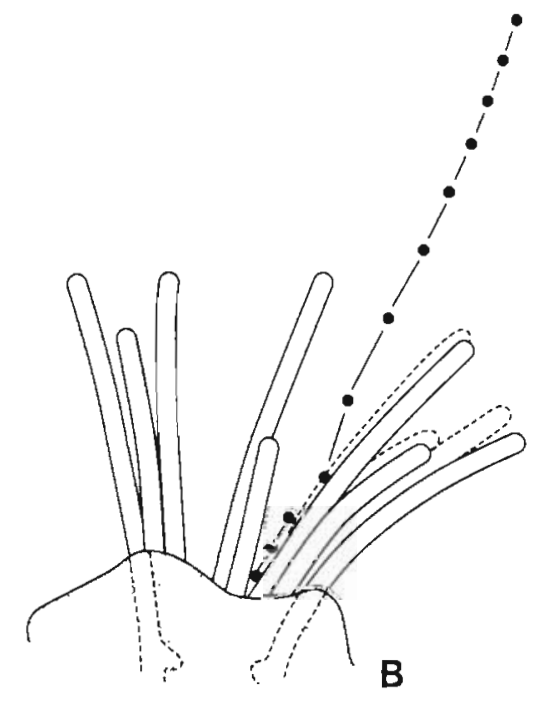



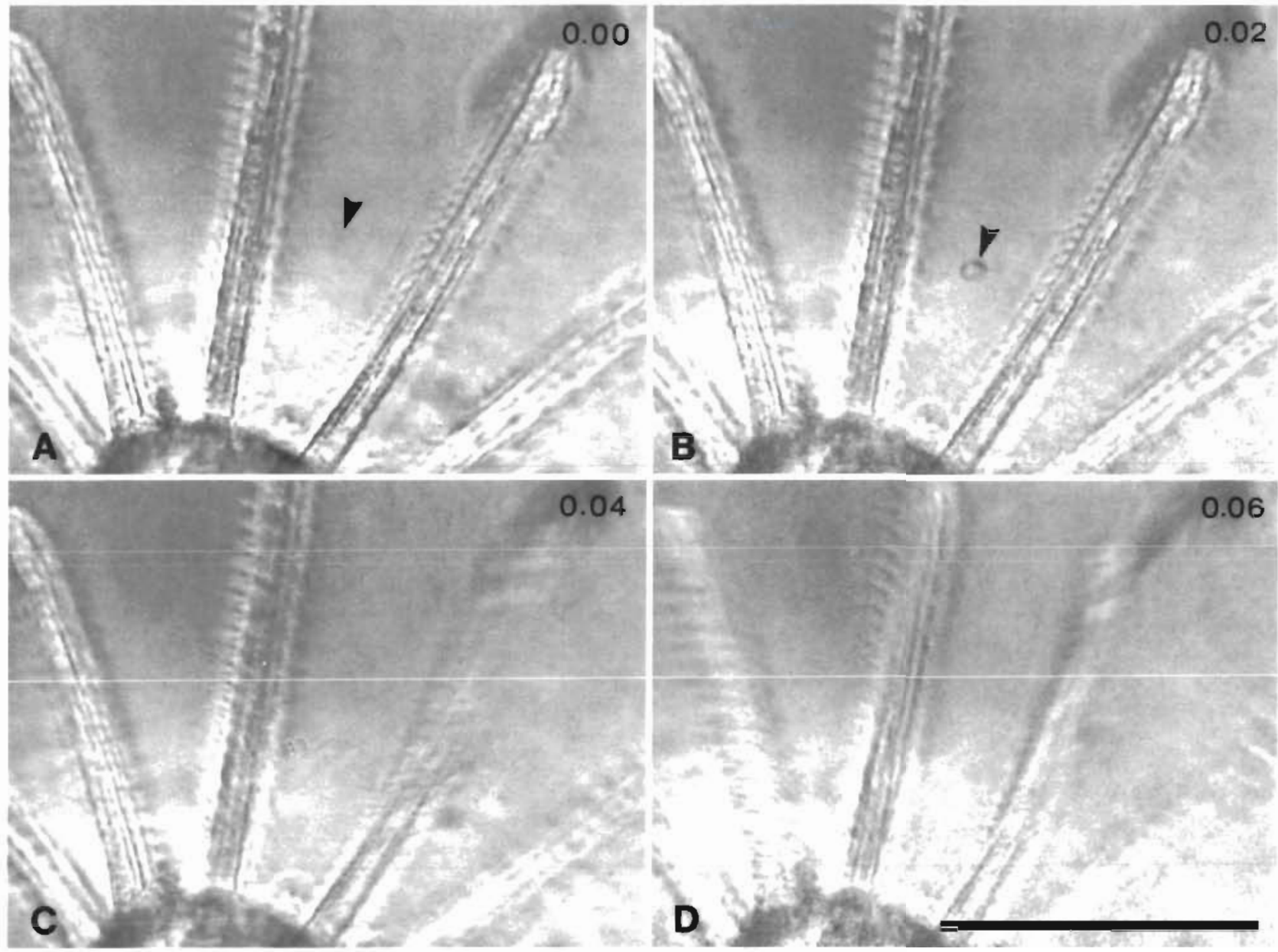

Fig. 14. Crisia eburnea. Video graphic prints $(0.02 \mathrm{~s}$ between pictures $)$ showing capture of a partic]e in the proximal part of the tentacle crown ( $A$ and $B$; the $6 \mu \mathrm{m}$ algal cell is indicated by an arrow) followed by 'collective' tentacle flicking (C and D) which brings the trapped particle into the central current of the tentacle crown. The tentacles are seen from the abfrontal side (metachronal waves run clockwise). Scale bar $=100 \mu \mathrm{m}$

gave a schematic drawing (based on transmission electron microscopy?) of a transverse section of a tentacle of Plumatella sp. The ultrastructure of cyclostome (stenolaemate) tentacles has not previously been studied in detail, but Nielsen (1987) pictured 2 sections and an SEM of a tentacle of Crisia eburnea. It now appears that the general architecture of all ectoproct tentacles shows little variation, with almost identical longitudinal rows of characteristic cell types; also the shape of the thickened basement membrane, which functions as a flexible skeleton, and of the mesodermal elements is uniform.

One row of frontal ciliated cells is found in the gymnolaemates, whereas there are about 5 cells across the frontal band in phylactolaemates. Cilia are apparently almost completely absent on the frontal cells in all cyclostomes; older, light-microscopical reports of cilia on the frontal side of the tentacles (Borg 1926) probably concern laterofrontal cilia. The presence of mucus- like inclusions in the apical part of the frontal cells could indicate that mucus is involved in the feeding mechanism, but this has not been supported by our observations. The secretions apparently have another, as yet unknown function.

Laterofrontal cells with a rather stiff cilium situated in a depression surrounded by a collar of microvilli are now well documented in gymnolaemates and cyclostomes, and their ultrastructure seems identical for example in details of ciliary basal structures. In phylactolaemates, Brien (1960) observed (light microscopically) 1 or 2 rows of such cells on each side of the tentacle in Cristatella mucedo, whereas cells with 1 stiff cilium were observed scattered between the multiciliate frontal cells in Plumatella fungosa. Gilmour (1978) pictured a row of monociliate laterofrontal cells in a highly diagrammatic drawing of Plumatella sp. Mukai et al. (1997) observed 2 types of cells on the frontal side of the tentacles of Pectinatella gelatinosa but were 


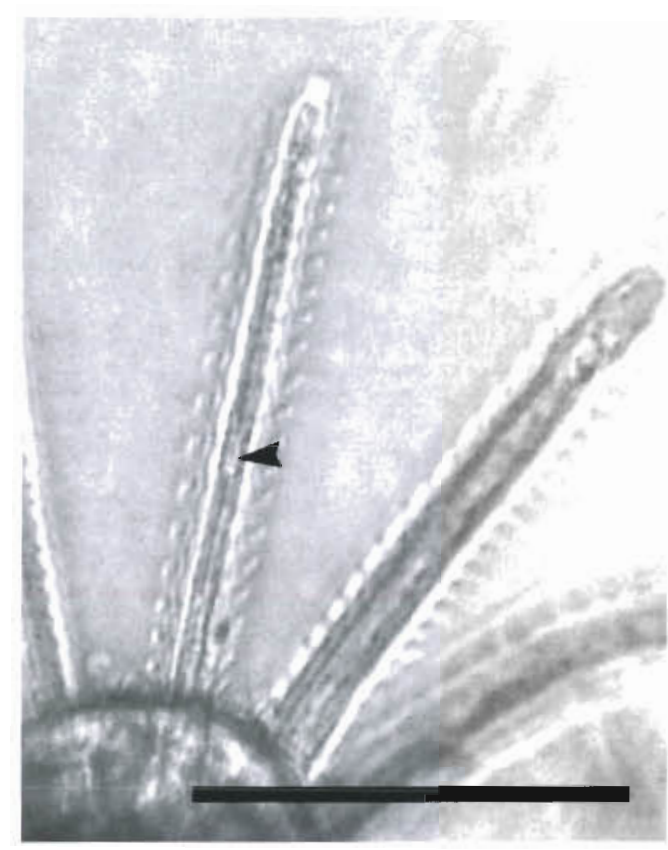

Fig. 15. Crisia eburnea. Instance of a particle (arrowhead) being trapped in the proximal part of the tentacle crown without immediately triggering a tentacle flick. The tentacle crown is seen from the frontal side. The metachronal waves run anti-clockwise and this pattern was unaltered during $0.32 \mathrm{~s}$ (16 video frames). Scale bar $=100 \mu \mathrm{m}$

unable to identify any of them as monociliate. Lutaud (1955) described the laterofrontal cilia of a gymnolaemate as 'soies tactiles', and the ultrastucture of all the laterofrontal cells strongly indicates that they are sensory. Gilmour (1978) mentioned that the bases of these cells form synapses with nerves along the tentacles in Plumatella sp., but he gave no documentation.

Paired rows of lateral cells are found in all 3 types of bryozoans, but the lateral ciliary bands comprise many rows of cilia in gymnolaemates and phylactolaemates, whereas the cyclostomes have only 1 row of extremely closely set cilia on each cell.

Our sections of retracted tentacles of Crisia eburnea show no coelomic cavity, and the configuration of the mesodermal cells with 1 large central cell does not indicate how a cavity can be formed in the expanded tentacles, as observed by Gordon (1974) in Cryptosula pallasiana. Borg (1926) described and illustrated a coelomic canal in the tentacles of all the species he studied, but this may be a misinterpretation of the rather empty looking central cell. However, a canal must be present in the tentacles from which the sperm is released (Silén 1972), but it is possible that the canal is only present in sexually mature male zooids. Isolated and narcotized tentacle crowns return to the normal funnel-shape probably due to the elastic properties of the thick basement membrane. Gordon (1974) sug- gested that the stretching of the tentacle crown of Cryptosula is accomplished by forcing fluid into the tentacles from the ring canal surrounding the mouth; this mechanism may be used by larger species, but is apparently not found in Crisia eburnea. The 2 longitudinal muscles are both situated frontal to the longitudinal keels of the basement membrane. This construction ensures that a contraction of the frontal muscle will cause a precise, frontally directed flicking, which pushes the arrested particle into the central current. Phylactolaemates, such as Plumatella fungosa and Pectinatella asajirensis do not have longitudinal keels on the basement membrane, but the longitudinal muscles resemble those of the other 2 groups with a frontal and an abfrontal strand (Brien 1960, Mukai et al. 1997). The speed of the active flicking stroke is 3 to 4 times faster than the return to the relaxed position, a movement which is probably passively accomplished by the basement membrane.

The function of the 4 longitudinal nerves in the tentacle of Crisia eburnea can only be inferred. Lutaud (1973) pictured a contact between a nerve fibre from the abfrontal nerve and the abfrontal muscle through a small pore in the basal membrane in Electra pilosa. Smith (1973) pictured connections between the frontal nerve and the frontal muscle. Gordon (in Mukai et al. 1997 ) reported a pair of lateral subperitoneal nerves in Cryptosula pallasiana but such nerves were not obvious in $C$. eburnea. It appears that the nerves along the bases of the laterofrontal cells are associated with these cells, possibly consisting of axons from the sensory cells, or possibly connected with them through synapses (Gordon 1974).

Both structure and inferred function of mouth and pharynx of Crisia eburnea corresponds closely to the descriptions given by Matricon (1973) for Alcyonidium polyoum and Gordon (1974) for Cryptosula pallasiana, except that $C$. eburnea apparently lacks the large vacuoles in the myoepithelial cells.

\section{Feeding in ectoprocts}

The present work demonstrates that the upstreamcollecting ciliary system in Crisia eburnea is based on a mechanical filter co-operating with tentacle flicking triggered by the captured particles to further transport the particles towards the mouth via the central current of the tentacle crown. These observations confirm and extend the results obtained by Riisgård \& Manríquez (1997), in particular by: (1) clarifying the tentacle structure, (2) stating that the stiff, presumably sensory, laterofrontal cilia are about $20 \mu \mathrm{m}$ long, stand in a row with a distance between each other of 3 to $4 \mu \mathrm{m}$, and form a mechanical filter which traps the particles in the 
feeding currents set up by the underlying very closely set 15 to $20 \mu \mathrm{m}$ long lateral cilia, and (3) presenting high magnification video pictures of the particlecapture process.

The lack of frontal cilia as well as the general similarity of tentacle structure in the cyclostomes studied in this work indicate that the particle-collection mechanism may be identical in all the cyclostomes, although for example Tubulipora sp. has 2 to 3 times longer tentacles than Crisia, which is one of the ectoproct genera with the shortest tentacles (Winston 1978, Riisgård \& Manríquez 1997)

The captured particles accumulate in the mouth region to be subsequently swallowed; but if the algal concentration is unnaturally high the normal feeding pattern breaks down due to overloading and satiation as described by Riisgård \& Goldson (1997). In the present work we have used algal concentrations representing naturally low phytoplankton levels to study the normal undisturbed feeding process. The algal concentration of 2800 cells $\mathrm{ml}^{-1}$ used in the present work was chosen because it is considered very important for the reliability of the feeding observations that the frequency of particles arriving to the tentacle crown is comparable with the typical situation in nature. Thus, a phytoplankton biomass of $5 \mu \mathrm{g}$ chlorophyll $\mathrm{a}^{-1}$ is the median value for Danish fjords and coastal waters between March and October, and this corresponds to 4000 Rhodomonas cells $\mathrm{ml}^{-1}$ (Riisgård \& Manríques 1997). Growth experiments performed by Riisgård \& Goldson (1997) have shown that the growth potential of ectoprocts may be fully utilized at about 4000 Rhodomonas cells $\mathrm{ml}^{-1}$, and because ectoprocts in general do not exploit their growth potential in nature, an algal concentration $<4000$ cells $\mathrm{ml}^{-1}$ was chosen in the present work. The pumping rate of Crisia eburnea was measured to be $0.14 \mathrm{ml} \mathrm{h}^{-1}$ zooid $^{-1}$ by Riisgård \& Manríques (1997), and this implies that the frequency of particle arrivals to the tentacle crown was $0.14 \times$ $2800 /(60 \times 60)=0.1 \mathrm{~s}^{-1}$, or 1 particle every tenth second. Therefore, when video recording particle capture in only a part of the tentacle crown or a single tentacle at high magnification, a relatively long recording time is needed. The above preconditions of studying particle capture in normally feeding ectoprocts resulted in recordings of tranquil zooids with a steady and continuous mode of filter-feeding. Thus, unsteadiness and 'vomiting' was only observed in 1 case where a concentration of 30000 cells $\mathrm{ml}^{-1}$ was used. It appears that most previous experiments performed by other workers have been carried out at too high algal concentrations [see Riisgård \& Manríquez (1997) and Riisgård \& Goldson (1997) for critical discussions of the literature].

The general structure of gymnolaemate tentacles resembles that of the cyclostomates described above, except that the gymnolaemates apparently all have frontal cilia. Both Strathmann (1973) and Riisgård \& Manriquez (1997) have demonstrated that trapped particles on the tentacles can be pushed into the central lophophore current by tentacle flicking similar to that described for Crisia eburnea. However, in Flustrellidra hispida, captured particles may also be transported along the frontal side of the tentacle, apparently by the frontal cilia (Riisgård \& Manríquez 1997, Fig. 8).

Strathmann $(1973,1982)$ hypothesized that both the particle trapping and the subsequent transport along the tentacle were caused by local reversals of the lateral ciliary band (Strathmann 1973, p. 132): 'This suggests that local reversals of lateral cilia help retain particles on the frontal surface during transport toward the mouth', and further: 'Thus, lateral cilia may be largely responsible for transporting particles along most of the tentacle'. However, in the accompanying drawing Strathmann (1973, Fig. 3) omitted the long laterofrontal cilia, which must form a barrier preventing particles from reaching the lateral cilia to 'induce' a reversal. Ryland (1976. Fig. 1.7) and Barnes (1987. Fig. 18-9) also ignored the possibility that the laterofrontal cilia could be an obstacle for particles to directly affect the lateral cilia. A disruption of the metachronal wave of the corresponding lateral ciliary band in connection with particle transport is clearly seen on Strathmann's high-speed films (1982). It is possible that the function of this change in the ciliary beat is to release the captured particle from the laterofrontal filter, so that it can either be transported by the central current after a tentacle flicking or be taken over by the frontal ciliary band.

Among the phylactolaemates, Fredericella sultana has an almost circular tentacle crown, which may function like those of the gymnolaemates, but other phylactolaemates have the tentacle crown extended laterally as a pair of curved arms forming a horseshoe (Brien 1960). The frontal sides of the tentacles face each other, and it is possible that the 'central' current of these species is a sheet-shaped current between the 2 rows of tentacles carrying the particles to the food groove at the base of the tentacles. This seems to be in agreement with Gilmour's (1978) observations. The method of particle capture may be similar to that of the gymmolaemates, but the variation in the arrangement of the laterofrontal cells and its importance for the feeding mechanism should be investigated further.

The planktotrophic cyphonautes larvae of Membranipora and a few other gymnolaemate genera have ciliary bands corresponding to those of 1 side of a gymnolaemate tentacle on a structure called the ciliated ridge, which separates incurrent and excurrent chambers between the 2 valves (Kupelwieser 1905 . Atkins 1955). Strathmann \& McEdward (1986) ob- 
served that larvae of $M$. membranacea and $M$. tuberculata retain algae and other particles on the anterior, i.e. upstream, side of the ridge, and that the particles after a short stop become transferred to the frontal ciliary band, which carries the particles to the mouth; reversal of the beat of the lateral cilia was not indicated. It was inferred that the particles are retained by the stiff laterofrontal cilia just as described above for Crisia eburnea (so, after all, cyphonautes does not 'break a biological rule'\}. Two stiff cilia are found on each laterofrontal cell forming a zigzag line with a distance between the cilia of 3 to $5 \mu \mathrm{m}$ (Nielsen 1987) and this corresponds well with the observations that particles down to about $5 \mu \mathrm{m}$ were retained. It is unclear how the retained particles are moved from the laterofrontal cilia to the frontal cilia, which transport the particles to the mouth; movements of the ciliated ridge have not been reported, but a small twitch of the mus. cle along the ciliated ridge may be enough to move the ridge a short distance towards the midline of the larva thereby bringing the frontal ciliary band, or perhaps rather its flow regime, in contact with the particle.

We conclude that particle capture in adult cyclostomates and gymnolaemates as well as of cyphonautes larvae is a mechanical filtering by the laterofrontal cilia. The captured particles are transported towards the mouth either by means of tentacle flicks which bring the particles into the central current or by frontal ciliary tracts. It remains unknown if changes in the beat of the lateral cilia play a role in connection with these processes.

\section{The ectoproct filter-pump}

The filter-pump design in ectoprocts is based on a relatively simple principle. The lateral 'pump' cilia provide the power to promote the feeding flow which passes through a mechanical filter formed by the stiff laterofrontal cilia (Fig. 16). The velocity $(u)$ of the ciliary driven feeding currents of the tentacle crown is typically about $1 \mathrm{~mm} \mathrm{~s}^{-1}$. The 'characteristic length (l) of a solid in the direction of the flow' (i.e. the width of a solid perpendicular to the flow) is given by the diameter of the tentacles (about $10 \mu \mathrm{m}$ ). The Reynolds number, $R e=l u / v$, where $v=$ kinematic viscosity $\left(10^{-6} \mathrm{~m}^{2} \mathrm{~s}^{-1}\right)$ is found to be 0.01 . The low Reynolds number $(R e \ll 1$ ) implies that creeping flow (i.e. smooth and vortex-free flow) surrounds the tentacles and the $0.2 \mu \mathrm{m}$ diameter laterofrontal cilia and that inertia
Fig. 16. Crisia eburnea. Sketch of filter-pump showing a cross section of the median part of the tentacle crown. Note the lack of frontal cilia. The beat of the lateral cilia has been drawn after SEM observations of lateral cilia of Heteropora magna (Fig. 11), where the active stroke appears to begin before the recovery stroke has stretched the cilium completely, as also mentioned by Aiello \& Sleigh (1972) for the lateral cilia of the Mytilus gill. The direction of the effective stroke is indicated by arrowheads. The lateral 'pump' cilia on the 8 tentacles provide the power to draw the water (long arrows) through the crown. Suspended food particles are separated from the flow by the sensory laterofrontal cilia which act as a mechanical filter. A retained particle triggers the tentacle to flick inwards, pushing the particle into the fast central current, which carries the particle to the mouth

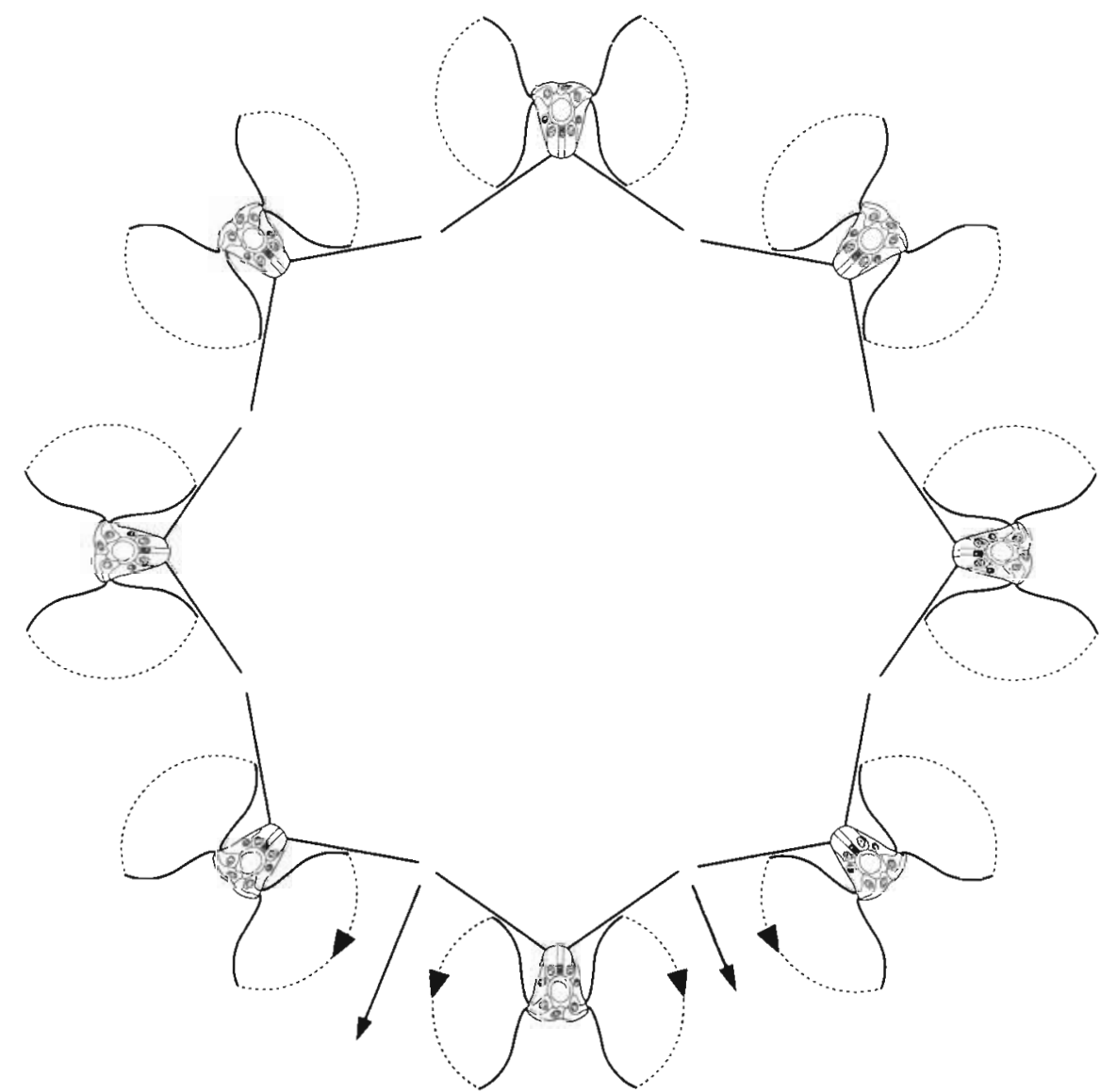


effects are negligible so that the neutrally buoyant $6 \mu \mathrm{m}$ diameter food particles used in the experiments follow the water motion with no slip until the particles are stopped by the laterofrontal filter (Purcell 1977, Vogel 1994). The drag force on the particle due to flow leaking throuch the laterofrontal ciliary array presumably deflects the cilia, which are presumably sensory, and this triggers a tentacle flick that transfers the captured particle to the laminar but relatively fast central current (Fig. 17). The tentacle tip velocity during a flick is 'only' about $0.5 \mathrm{~mm} \mathrm{~s}^{-1}$ (Riisgård \& Manriques 1997), which still implies creeping flow conditions for the particle-transfer situation. To further understand the ectoproct filter-pump it may be appropriate to compare it with the bivalve filter-pump.

Velocity gradients produced by the lateral 'pump' cilia in mussel Mytilus edulis show that the velocity of water propelled by the cilia increases with distance from the ciliated cell surface to reach a maximum value of about $3 \mathrm{~mm} \mathrm{~s}^{-1}$ at the ciliary tip beyond which the flow rate decreases to $0.6 \mathrm{~mm} \mathrm{~s}^{-1}$ at 4 cilium lengths above the cell surface (Nielsen et al. 1993). The dura-

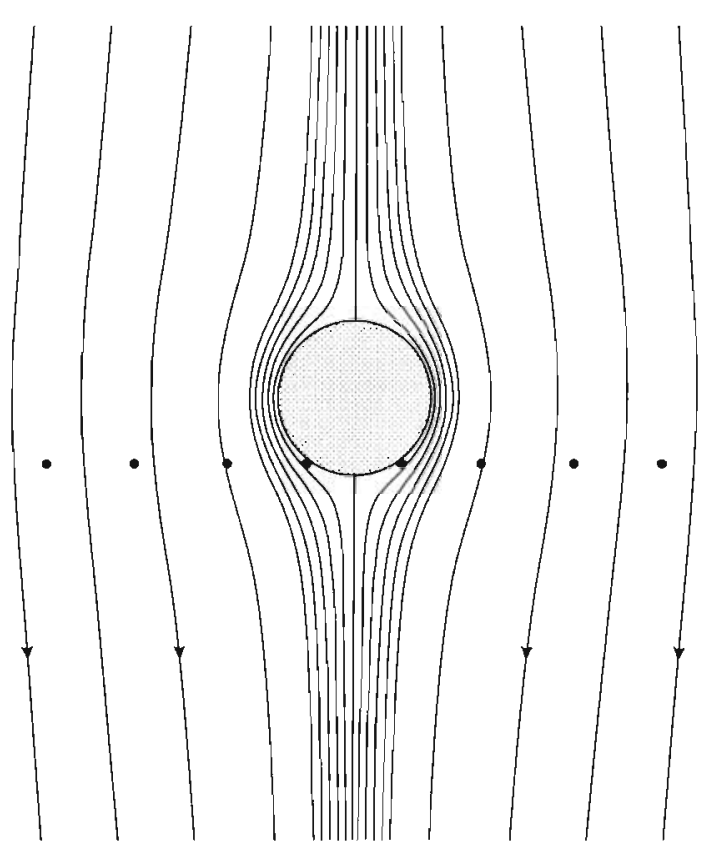

Fig. 17. Theoretical streamlines for creeping flow through the laterofrontal ciliary filter which has stopped a $6 \mu \mathrm{m}$ algal cell (shaded). The drag force on the food particle presumably deflects the $0.2 \mu \mathrm{m}$ diameter sensory laterofrontal cilia (dots), and this triggers the tentacle flick. The sketch is based on streamlines calculated by Dr P. Scheel Larsen (Technical University of Denmark) for a single sphere in an infinite fluid at. $R e=0$. The upstream flow is laminar, steady and uniform, and there is no substantial streamline compression around the sphere, which, however, disturbs the flow far away (possibly 5 diameters). The laterofrontal cilia (probably) do not influence the flow tion of the active lateral ciliary beat in Crisia eburnea (assumed to be $1 / 5$ of the beat cycle) may be estimated on the basis of the observed beat frequency of $25 \mathrm{~Hz}$ (Fig. 15) to be about $1 / 5 \times 1 / 25=1 / 125$ s. During this time a $15 \mu \mathrm{m}$ long lateral cilium sweeping a suggested $150^{\circ}$ arc (like the lateral cilia in $M$. edulis, Sleigh \& Aiello $1972)$ would attain a mean tip velocity of $(150 / 360) \times 2 \pi$ $\times 0.015 \times 125=4.9 \mathrm{~mm} \mathrm{~s}^{-1}$ The average speed of water near the ciliary tip may therefore be predicted to be $1 / 5 \times 4.9=1 \mathrm{~mm} \mathrm{~s}^{-1}$. Including a minor negative effect of the recovery stroke the velocity may be estimated to somewhat less, i.e. about $0.8 \mathrm{~mm} \mathrm{~s}^{-1}$, which is in good agreement with video recorded velocities of particles entering the filter zone of C. eburnea (see Fig. 12; Riisgård \& Manriquez 1997, Fig, 6). For later reference this observed value will be used as a reasonable estimate of the velocity near the tip of the laterofrontal cilia.

Retention efficiency has recently becn mcasured in 2 ectoprocts. It was found that particles $>5 \mu \mathrm{m}$ in diameter are retained with near $100 \%$ efficiency in both Celleporella hyalina (Riisgård \& Manriquez 1997. Fig. 5) and Electra crustulenta (Riscrătr \& Goldson 1997). This shows that the spacing between the $0.2 \mu \mathrm{m}$ diameter laterofrontal cilia may be about $5 \mu \mathrm{m}$. In the present work the spacing of the laterofrontal cilia in Crisia eburnea was found to be smaller, about $3.5 \mu \mathrm{m}$.

It is somewhat problematic to obtain an accurate estimate of the pressure drop across the laterofrontal filter because of its geometry and because the water is not leaking through the ciliary filter array with the same velocity along the length of the cilia, from tip to base. The maximum velocity is found near the tip, where the velocity is about $u_{t}=0.8 \mathrm{~mm} \mathrm{~s}^{-1}$. From the tip towards the base the velocity decreases concurrently with a shorter turning length of the actively beating lateral cilia, to finally become zero at some distance above the base due to the negative effect of the reversals of the lateral cilia. Fowever, for an approximate estimate of the pressure drop across the laterofrontal filter in ectoprocts a flat screen of parallel cylinders with a mean diameter of $d$ and spacing $b$ may be considered a usable model. For a flat screen consisting of parallel cylinders forming a mesh of infinite extent the pressure drop $\left(\triangle \mathrm{H}\right.$ in $\mathrm{mm} \mathrm{H}_{2} \mathrm{O}$ ) is given by the equation of Tamada \& Fujikawa (see Riisgård \& Larsen 1996, Eq. 1): $\Delta H=K v u_{\infty} / g d$, where $K=8 \tau /(1-2 \ln \tau+$ $\left.\tau^{2} / 6\right), \tau=\pi(d / b), u_{\infty}$ the velocity of unrestricted upstream flow, $g=$ acceleration of gravity $\left(9.807 \mathrm{~m} \mathrm{~s}^{-2}\right)$, and $v=$ kinematic viscosity of water $\left(1.1 \times 10^{-6} \mathrm{~m}^{2} \mathrm{~s}^{-1}\right)$. Assum. ing $d=0.2 \mu \mathrm{m}, b=3.5 \mu \mathrm{m}$ and $u_{\infty}=u_{l}=0.8 \mathrm{~mm} \mathrm{~s}^{-1}$, the pressure drop is $\Delta H=0.13 \mathrm{~mm} \mathrm{H}_{2} \mathrm{O}$.

Since $\Delta H$ is directly proportional to $u_{\infty}$ the pressure drop across the laterofrontal filter is readily determined for velocities lower than the mean ciliary tip velocity of $0.8 \mathrm{~mm} \mathrm{~s}^{-1}$ by simple scaling. Assuming the 
velocity past the laterofrontal ciliary mesh to diminish to zero at the root of the laterofrontal cilia, the pressure drop would vary similarly. Because a realistic mean flow velocity through the laterofrontal filter may be estimated to be about $0.4 \mathrm{~mm} \mathrm{~s}^{-1}$, the true pressure drop may be as low as $0.065 \mathrm{~mm} \mathrm{H}_{2} \mathrm{O}$.

A further contribution to pump-system resistance to flow comes from the global flow established in and around the ectoproct, which is believed to be small compared to that due to the laterofrontal filter. It is noted that the total flow resistance in Mytilus edulis is about 15 times that offered by the laterofrontal filter of Crisia eburnea (Jørgensen et al. 1986, Riisgård \& Larsen 1995). The ciliary pump in C. eburnea consists of only 2 parallel rows of cilia (Figs. 1, $2 \& 5$ ) whereas the much more powerful pump in $M$. edulis consists of a $10 \mu \mathrm{m}$ wide ciliary band with oblique $\left(40^{\circ}\right)$ rows of 35 cilia, each with the same diameter and spacing between them of $0.2 \mu \mathrm{m}$ (Aiello \& Sleigh 1972, Sleigh \& Aiello 1972).

The special ectoproct filter-pump design creates velocity gradients with the highest velocity in the central core at the entrance. Particles entering the tentacle crown in this core of 'stagnating' water (i.e. with a velocity decreasing to zero at the bottom of the tentacle crown) may thus be brought directly to the mouth without physical contact with the laterofrontal ciliary filter. The quantitative importance of particles captured by the 'stagnating water principle' may at a rough estimate be assessed by assuming that particles in the central core with a radius ( $r$ ) of $10 \mu \mathrm{m}$ are being conveyed directly to the mouth without physical contact with the laterofrontal filter. In the case of Crisia eburnea the following estimation can be made. The central water flow velocity is $v_{c}=0.2 \mathrm{~cm} \mathrm{~s}^{-1}$ (Fig. 12) and thus the central core volume flow is $Q_{\text {core }}=v_{c} \pi r^{2}=$ $0.002 \mathrm{ml} \mathrm{h}^{-1}$, which may be compared to the total volume of water mechanically filtered $=F=25 \%$ of total tentacle crown volume flow $Q_{\text {tof }}=0.25 \times 0.14=$ $0.035 \mathrm{ml} \mathrm{h}^{-1}$ zooid $^{-1}$ (Riisgård \& Manriquez 1997). Thus, $Q_{\text {core }} / F=0.002 / 0.035=6 \%$ of all the particles captured may be conveyed directly to the mouth. Particle capture in the central water current is a normal part of the feeding process in all ectoprocts, but the quantitative importance for food uptake may be insignificant (about 5\%),

\section{Upstream-collecting ciliary bands and phylogeny}

It has generally been assumed that because the upstream-collecting ciliary bands of ectoprocts, phoronids, brachiopods, echinoderms, pterobranchs, and enteropneusts have roughly similar structures they may have identical function (Strathmann 1973 and most of this subsequent publications mentioned in the literature cited, but see also Hart \& Strathmann 1995). The gills of the autobranch bivalves likewise have upstreamcollecting ciliary systems, but of completely different structures and functions (Riisgård et al, 1996. Silverman et al. 1996) and they will not be discussed here. Structural differences between the ectoprocts, which have multiciliate cells in the lateral and frontal bands, and the other groups, which have only monociliate cells, have been pointed out by Nielsen $(1987,1995)$, who attached phylogenetic importance to this difference. Our observations have demonstrated that the filtering mechanism of cyclostomate ectoprocts is mechanical with the laterofrontal cilia forming the filter, and this is in full accordance with the observations on gymnolaemates by Riisgård \& Manríquez (1997).

Previous theories for the function of upstreamcollecting bands have included ciliary reversal, impingement or alternative fluid mechanical principles (see next section), and it seems important to compare our observations on the ectoprocts with those on the other phyla as reported in the literature (Table 1).

Both larval and adult phoronids have frontal, laterofrontal and lateral ciliary bands on the tentacles (Nielsen 1987). The actinotroch larva has unusually long laterofrontal cilia surrounded by a conspicuous collar of long microvilli whereas the adult phoronids have laterofrontal cells with a collar of short microvilli (Strathmann 1973, Gilmour 1978, Nielsen 1987). Neither juveniles nor most adults have a circular or compressed lophophore with a central mouth, so a central current like that of the ectoprocts must be absent. Tentacle flicking has not been reported, and the structure of the tentacles with a uniform, rather thin basement membrane and a thin layer of muscle cells surrounding the coelom (Pardos et al. 1991) does not indicate a preferred direction of bending. This makes it unlikely that the larvae have a particle-collecting mechanism like that of the gymnolaemates, with particles captured by the laterofrontal cilia. Particle capture by ciliary reversal has been suggested for both larvae and adults by Strathmann (1973), but further investigations are needed.

Frontal and lateral ciliary bands are found on the tentacles of both larval and adult brachiopods, but only the lingulids, i.e. larvae of Lingula anatina and adults of Glottidia pyramidata, have been reported to have cells with a cilium surrounded by special microvilli like the laterofrontal cells of the adult phoronids (Gilmour 1981, Nielsen 1987). Larval linguliform brachiopods (lingulaceans and discinaceans) and juvenile articulate brachiopods have an almost circular lophophore with a wide oral field (Nielsen 1987, Rudwick 1962). Their feeding has not been studied in detail, but the geometry of the lophophores excludes the possibility of a central current. Adult brachiopods generally have 
Table 1. Characteristics of upstream-collecting ciliary bands in various animal groups (bivalves omitted). Mono, monocillate cells; multi, multiciliate cells; + , present; -, absent

\begin{tabular}{|c|c|c|c|c|c|}
\hline & Frontal cells & Latero-frontal cells & Lateral cells & Tentacles & Flicking \\
\hline \multicolumn{6}{|c|}{ Ectoprocta } \\
\hline Adults & Multi & + & Multi & + & + \\
\hline \multicolumn{6}{|c|}{ Gymnolaemata } \\
\hline Larvae & Multi & + & Multi & - & ? \\
\hline Adults & Multi & + & Multi & + & + \\
\hline \multicolumn{6}{|c|}{ Phylactolaemata } \\
\hline Adults & Multi & + & Multi & + & $?$ \\
\hline \multicolumn{6}{|l|}{ Phoronida } \\
\hline Larvae & Mono & + & Mono & + & ? \\
\hline Adults & Mono & + & Mono & + & $?$ \\
\hline \multicolumn{6}{|c|}{ Brachiopoda } \\
\hline \multicolumn{6}{|c|}{ Linguliformea } \\
\hline Larvae & Mono & + & Mono & + & ? \\
\hline Adults & Mono & + & Mono & + & - \\
\hline \multicolumn{6}{|c|}{ Cranifformea } \\
\hline Adults & Mono & - & Mono & + & - \\
\hline \multicolumn{6}{|l|}{ Articulata } \\
\hline Adults & Mono & - & Mono & + & - \\
\hline \multicolumn{6}{|c|}{ Echinodermata } \\
\hline Larvae & (Mono) & - & Mono & - & - \\
\hline \multicolumn{6}{|c|}{ Pterobranchia } \\
\hline Adults & Mono & - & Mono & + & - \\
\hline \multicolumn{6}{|c|}{ Enteropneusta } \\
\hline Larvae & (Mono) & - & Mono & - & - \\
\hline
\end{tabular}

intricate lophophore arms extending from the lateral parts of the mouth region. The tentacles are arranged in a zigzag pattern of inner (adlabial) and outer (ablabial) tentacles of different shapes along the 2 sides of the lophophore arms. The inner tentacles have a narrow ciliated frontal surface whereas the outer tentacles have a wide ciliated frontal gutter (Reed \& Cloney 1977, James 1997). Gilmour (1978) noted that the accessory centrioles of the frontal cilia have opposite locations in the inner and outer tentacles with the centrioles on the distal side of the ciliary root (towards the tip of the tentacles) in the inner tentacles, whereas they are situated on the proximal side in the outer tentacles; this indicates that the effective strokes of the cilia of the 2 bands are different (Nielsen 1987), with the band of the inner tentacles transporting particles towards the tip of the tentacle and that of the outer tentacles transporting particles towards the base of the tentacle and probably further towards the mouth. Particle transport in undisturbed specimens is difficult to observe because of the shells, but Dhar et al. (1997) studied particle trajectories at the lophophores of Terebratulina septentrionalis and Terebratalia transversa by means of an endoscope. It was observed that particles captured on the frontal ciliary band of the inner tentacles were transported towards the tip of the ten- tacle whereas particles caught by the outer tentacles move along the frontal ciliary band to the brachial groove that leads to the mouth. The actual method of particle retention has not been demonstrated. Strathmann (1973) suggested a ciliary reversal method, but this was criticized by Gilmour $(1978,1981)$, who proposed that the brachiopods could separate heavier particles through an impingement method and retain lighter particles through an unspecified process.

Larvae of echinoderms (Strathmann 1971, Hart 1991) and enteropneusts (Strathmann \& Bonar 1976) and Planktosphaera pelagica (Hart et al. 1994) have upstream-collecting ciliary bands surrounding a sparsely ciliated or unciliated oral field. Pluteus larvae have long arms with ciliary bands with a calcareous skeleton, so flicking movements are excluded. Bipinnaria and brachiolaria larvae have long arms with ciliary bands, but these arms are soft, obviously incapable of the rapid flicking movements observed in adult ectoprocts. There are no reports of structures resembling the stiff laterofrontal cilia seen in ectoprocts, so it is obvious that the particle-capture mechanism is not the same as that of the ectoprocts. Studies of the current set up by the swimming and feeding larvae have demonstrated that the cilia can reverse their beat so that the whole larva 'goes in reverse', and local rever- 
sal of ciliary strokes in connection with particle capture is indicated by observations using high-speed film (Strathmann et al. 1972, Hart 1991). Hart (1990) observed that about $5 \%$ of the particles captured by the various echinoderm larvae did not come in contact with the ciliary bands and this may correspond to the particles in the central current in ectoprocts which reach the mouth without contact with the tentacles. This could be the mechanism inferred by Gilmour $(1978,1985,1986)$. It appears that the ciliary feeding mechanism of these forms is not identical to any of those reported above from the ectopocts.

The pterobranchs Rhabdopleura normani and Cephalodiscus gracilis have lateral ciliary bands consisting of 2 rather closely set rows of cilia, resembling lateral ciliary bands of ophiopluteus larvae (see Nielsen 1995. Fig. 43.3E), and scattered cilia on both the frontal and the abfrontal side (Dilly et al. 1986, Nielsen 1987 , Halanych 1993, Benito \& Pardos 1997). The lateral cilia are surrounded by a ring of 7 short microvilli but there is no pit at the ciliary base as in the laterofrontal cells for example of Crisia and the phoronids (Benito \& Pardos 1997). Both Gilmour (1979) and Halanych (1993) reported the presence of laterofrontal cilia, but no cells resembling the laterofrontal cells in ectoprocts, phoronids or brachiopods were shown in the transmission micrographs. Halanych (1993) further reported the presence of a row of holes at the bases of the tonta cles, through which rejected particles should pass. However, the accompanying light micrograph (Halanych 1993, Fig. 3) shows a 'hole' with cytological structures, such as pigment bodies, extending into the hole, so the holes may represent a misinterpretation. Halanych (1993) observed flicking movements of the tentacles but was unable to relate these to particle capture. The observations of Gilmour (1979), Dilly (1985), Lester (1985), and Halanych (1993) all show that the pterobranchs are upstream-collecting filter feeders, but the mechanism of particle capture is undocumented. Dilly (1985) observed particles of borax carmine or carbon being trapped in mucus which moved along the frontal side of tentacles and arms toward the mouth, but it is unknown whether mucus is involved in feeding on natural food particles.

Tornaria larvae and Planktosphaera pelagica have upstream-collecting ciliary bands without laterofrontal cilia; flicking mechanisms have not been reported and the morphology of the larvae makes it unlikely that they can be performed (Strathmann \& Bonar 1976 , Gilmour 1982, Hart et al. 1994).

It seems clear that 2 particle-retention methods are employed by the upstream-collecting phyla discussed above. The cyclostome bryozoans rely exclusively on mechanical sieving by the laterofrontal cilia, and the trapped particles are pushed to the central current by tentacle flicking. The gymnolaemates have the same mechanism, but captured particles may also be transported to the mouth on the frontal ciliary band. The phylactolaemates need further study. A completely different mechanism is found in adult craniid and articulate brachiopods and pterobranchs and in the larvae of echinoderms and enteropneusts, which all lack the laterofrontal cilia and are probably all incapable of flicking movements. The phoronids have laterofrontal cilia, but the particle-capture method is not well described. This indicates that the filter-feeding structures of the ectoprocts are not homologous with the mechanism of the other groups just mentioned, and further supports the view that the 'Lophophorata' is a polyphyletic group, with phoronids and brachiopods closely related to the core deuterostomes (Nielsen 1995). It is further indicated that the term upstream-collecting filter-feeding covers 2 different types, so that 1 (or 2 ) new terms should perhaps be created.

\section{Sieving and ciliary filters}

The mechanisms by which suspension feeding animals catch particles are largely unknown, and biologists have been blamed for assuming that biological filters always act as sieves. Thus, Vogel (1994) claimed that sieves are relatively unusual biological filters, and that the turning point in how the filtering process ought to be viewed came with the filtration theory presented by Rubenstein \& Koehl (1977), who made a number of theoretical considerations to illustrate that filter feeders need not be restricted to sieving. The filtration theory, previously used by engineers in predicting the effectiveness of particle removal by aerosol filters, deals with mechanisms by which particles make contact with a filter feeder (and not the mode of retention of particles by the animal's filter). Thus, 5 mechanisms were suggested by means of which a fiber may remove dispersed particles from a velocity field: direct interception, inertial impaction, gravitational deposition, diffusional deposition, and electrostatic attraction. Among these possibilities it was found that direct interception was likely to be the main mode of capture. But direct observations were missing. Later, by surveying the literature on feeding structures and particlecapture characteristics, LaBarbera (1984) came to a somewhat modified suggestion, namely that 6 distinct mechanisms of particle capture may be used, either alone or in combination, by filter feeding organisms. The suggested mechanisms were both biological ('scan and trap', which involves active response for capture) and physical (i.e. sieving, direct interception, inertial impaction, gravitational deposition, and diffusive deposition). Among these possibilities LaBarbera claimed 
that the best evidence for the occurrence of the 'scan and trap' mechanism in suspension feeding animals other than copepods comes from the work of Strathmann and co-workers (cited in LaBarbera 1984) on upstream-collecting invertebrates: adult bryozoans, echinoderm larvae, adult brachiopods and phoronids, and the tornaria larvae of hemichordates. According to the 'scan and trap' theory a local ciliary reversal alters the flow so that a small parcel of water containing the particle is isolated on the upstream side of a band of simple cilia. This interpretation is not in agreement with the present work, which argues for a sieving mechanism with tentacle flicking in ectoprocts. A sieving mechanism is also in agreement with the particle-retention spectrum measured by Riisgård \& Manriquez (1997), and with their finding that the product of filter area and water velocity is a credible measure of clearance of assumed $100 \%$ retained particles.

It is obvious that further investigations are needed to clarify if alternative bio-fluid-mechanical principles may be at work in other groups of ciliary upstreamcollecting invertebrates (e.q. Jørgensen 1983. Jørgensen et al. 1984, Silvester 1988, Shimeta \& Jumars 1991, Hart \& Strathmann 1995, Wildish \& Kristmanson 1997), but sieving in groups other than mucus-net filter feeders may certainly not be an unusual mechanism for suspension feeders. Thus, Fenchel (1984) pointed out that the mechanisms available for bacterivores in the pelagic food chains may be either sieving, direct interception or diffusion. Only the smallest phagotrophs (e.g. chrysomonads, heliozoans) were found to use diffusion or direct interception as a means to concentrate bacteria whereas suspension feeding ciliates and microflagellates (i.e. choanoflagellates and helioflagellids) depended on sieving. In the ciliates the filter consists of a parallel array of cilia with various distance dependent on species, i.e. down to $0.3 \mu \mathrm{m}$ in fine filters and up to $8 \mu \mathrm{m}$ in coarser filters (Fenchel 1980, Fig. 2). Because the water velocity through the filter is correlated with porosity, Fenchel found in all cases that the pressure drop over the filter was about $0.3 \mathrm{~mm} \mathrm{H}_{2} \mathrm{O}$, which may be compared to $0.065 \mathrm{~mm} \mathrm{H}_{2} \mathrm{O}$ found for Crisia eburnea in the present work. Although the hydrostatic pressure that a ciliary pump can support is restricted, maximally about $1 \mathrm{~mm} \mathrm{H}_{2} \mathrm{O}$ (Riisgård \& Larsen 1996), the filter-resistance in ciliary filterfeeders does not exclude a sieving mechanism.

Acknowledgements. Our thanks are due to Mrs Birgitte Rubak and Mr Gert Brovad for help with the illustrations and to Dr C. Barker Jorgensen (University of Copenhagen), Dr P. Scheel Larsen (Technical University of Denmark), Dr R. R. Strathmann (Friday Harbor Laboratories), Dr M. LaBarbera (The University of Chicago) and Dr Beth Okamura (University of Reading) for constructive comments on an earlier version of the manuscript. H.U.R. was supported by a grant from the Danish National Science Research Council (no. 28-808) during his sabbatical stay at the School of Biological Sciences, University of Wales, Bangor, where parts of the work were carried out. Other parts were carried out at Kristmeberg Marine Research Station. Sweden. We are grateful for all the support received at the 2 institutions. C.N. was supported by a project grant from the Danish National Science Research Council (no. 11-9652).

\section{LITERATURE CITED}

Aiello E. Sleigh MA (1972) The metachronal wave of lateral cilia of Mytilus edulis. J Cell Biol 54:493-506

Atkins D (1932) The clliary feeding mechanism of the entoproct Polyzoa, and a comparison with that of the ectoproct Polyzoa. Q J Microsc Sci 75:393-423

Atkins D (1955) The ciliary feeding mechanism of the cyphonautes larva (Polyzoa Ectoprocta). J Mar Biol Assoc UK 34: $451-466$

Bames RD (1987) invertebrate zoology. Saunciers College Publishing, Philadelphia

Benito J, Pardos F (1997) Hemichordata. In: Harrison FW (ed) Microscopic anatomy of invertebrates, Vol 15. Wiley-Liss, New York, p 15-101

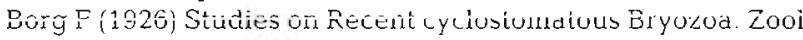
Bidr Upps 10:181-507, 10 pls

Brien P (1960) Classe des Bryozoaires. Traité de Zoologie, Vol 5, tasc. 2. Masson, Paris, p 1053-1335

Bullivant JS (1968) The method of feeding of lophophorates (Bryozoa, Phoronida, Brachiopoda). N Z J Mar Freshwat Res 2:135-146

Dhar SR, Logan A, MacDonald BA, Ward EJ (1997) Endoscopic investigations of feeding structures and mechanisms in two plectolophous brachiopods. Invertebr Biol 116:142-150

Dilly PN (1985) The habitat and behaviour of Cephalodiscus gracilis (Pterobranchia, Hemichordata) from Bermuda. J Zool (Lond) A. 207:223-239

Dilly PN, Welsch U, Rehkämper G (1986) Fine structure of tentacles, arms and associated structures of Cephalodiscus gracilis (Pterobranchia, Hemichordata) Acta Zool (Stockh) 67:181-191

Fenchel T (1980) Relation between particle size selection and clearance in suspension-feeding ciluates. Limnol Oceanogr 25:733-738

Fenchel T (1984) Suspended bacteria as a food source. In: Fasham MJR (ed) Flows of energy and materials in manne ecosystems. Plenum Press, New York, p 301-315

Gallager SM (1988) Visual observations of particle manipulation during feeding in larvae of a bivalve mollusc Bull Mar Sci 43:344-365

Gilmour THJ (1978) Ciliation and function of the foodcollecting and waste-rejecting organs of lophophorates. Can J Zool 56:2142-2155

Gilmour THJ (1979) Feeding in pterobranch hemichordates and the evolution of gill slits. Can J Zool 57:1136-1142

Gilmour THJ (1981) Food-collecting and waste-rejecting mechanisms in Glottidia pyramidata and the persistence of lingulacean inarticulate brachiopods in the fossil record. Can J Zool 59:1539-1547

Gilmour THJ (1982) Feeding in tornarla larvae and the development of gill slits in enteropneust hemichordates. Can J Zool 60:3010-3020

Gilmour THJ (1985) An analysis of videotape recordings of larval feeding in the sea urchin Lytechinus pictus Verrill. Can J Zool 63:1354-1359 
Gilmour THJ (1986) Streamlines and particle paths in the feeding mechanisms of larvae of the sea urchin Lytechinus pictus Verrill. J Exp Mar Biol Ecol 95:27-36

Gordon DP (1974) Microarchitecture and function of the lophophore in the bryozoan Cryptosula pallasiana. Mar Biol 27:147-163

Gordon DP, Clark AG, Harper JF (1987) Bryozoa. In: Pandian TJ, Vernberg FJ (eds) Animal energetics, Vol 2. Academic Press, London, p 173-199

Halanych KM (1993) Suspension feeding by the lophophorelike apparatus of the pterobranch hemichordate Rhabdopleura normani. Biol Bull (Woods Hole) 185:417-427

Hart MW (1990) Manipulating external $\mathrm{Ca}^{2+}$ inhibits particle capture by planktotrophic echinoderm larvae. Can J Zool 63:2610-2615

Hart MW (1991) Particle captures and the method of suspension feeding by echinoderm larvae. Biol Bull (Woods Hole) 180:12-27

Hart MW (1996) Deconstructing suspension feeders by analysis of film and video. Invertebr Biol 115:185-190

Hart MW, Miller RL, Madin LP (1994) Form and feeding mechanism of a living Planktosphaera pelagica (phylum Hemichordata). Mar Biol 120:521-533

Hart MW, Strathmann RR (1995) Mechanisms and rates of suspension feeding. In: McEdward L (ed) Ecology of marine invertebrate larvae. Marine Science Series, CRC Press, Boca Raton, FL, p 193-221

James MA (1997) Brachiopoda: internal anatomy, embryology and development. In: Harrison FW (ed) Microscopic anatomy of invertebrates, Vol 13. Wiley-Liss, New York, p $297-407$

Jørgensen CB (1983) Fluid mechanical aspects of suspension feeding. Mar Ecol Prog Ser 11:89-103

Jorgensen CD, Famme P, Kristensen HS, Larsen PS, Mahlenberg F, Riisgård HU (1986) The bivalve pump. Mar Ecol Prog Ser 34:69-77

Jørgensen CB, Kiørboe T, Møhlenberg F, Riisgård HU (1984) Ciliary and mucus-net filter feeding, with special reference to fluid mechanical characteristics. Mar Ecol Prog Ser $15: 283-292$

Kupelwieser $H$ (1905) Untersuchungen über den feineren Bau und die Metamorphose des Cyphonautes. Zoologica (Stuttgart) 47:1-50, 5 pls

LaBarbera M (1984) Feeding currents and particle capture mechanisms in suspension feeding animals. Am Zool 24 . $71-84$

Lester SM (1985) Cephalodiscus sp. (Hemichordata: Pterobranchia): observations of functional morphology, behaviour and occurrence in shallow water around Bermuda. Mar Biol 85:263-268

Lutaud G (1955) Sur la ciliature du tentacule chez les Bryozoaires Chilostomes. A.rchs Zool Exp Gén 92 (Notes et Revue): $13-19$

Lutaud G (1973) L'innervation du lophophore chez le Bryozoaire chilostome Electra pilosa (L.). Z Zellforsch Mikrosk Anal 140:217-234

Matricon I (1973) Quelques données ultrastructurales sur un myoépithelium: le pharynx d'un Bryozoaire. Z Zellforsch Mikrosk Anal 136:569-578

Mayer S (1994) Particle capture in the crown of the ciliary suspension feeding polychaete Sabella penicillus: videotape recordings and interpretations. Mar Biol 119:571-582

Mukai H, Terakado K, Reed CG (1997) Bryozoa. In: Harrison FW (ed) Microscopic anatomy of invertebrates, Vol 13 Wiley-Liss, New York, p 45-206

Nielsen C (1987) Structure and function of metazoan ciliary bands and their phylogenetic significance. Acta Zool
(Stockh) 68:205-262

Nielsen C (1995) Animal evolution: interrelationships of the living phyla. Oxford University Press, Oxford

Nielsen C, Pedersen KJ (1979) Cystid structure and protrusion of the polypide in Crisia (Bryozoa, Cyclostomata). Acta Zool (Stockh) 60:65-88

Nielsen C, Rostgaard J (1976) Structure and function of an entoproct tentacle with a discussion of ciliary feeding types. Ophelia 15:115-140

Nielsen C. Scharff N, Eibye-Jacobsen D (1996) Cladistic analyses of the animal kingdom. Biol J Linn Soc 57 : $385-410$

Nielsen NF, Larsen P, Riisgård HU, Jørgensen CB (1993) Fluid motion and particle retention in the gill of Mytilus edulis: video recordings and numerical modelling. Mar Biol 116: $61-71$

Pardos F, Roldán C, Benito J, Emig CC (1991) Fine structure of the tentacles of Phoronis australis Haswell (Phoronida, Lophophorata). Acta Zool (Stockh) 72:81-90

Purcell EM (1977) Life at low Reynolds number. Am J Phys 45:3-11

Reed CG, Cloney RA (1977) Brachiopod tentacles: ultrastructure and functional significance of the connective tissue and myoepithelial cells in Terebratalia. Cell Tissue Res $185: 17-42$

Riisgărd HU, Goldson A (1997) Minimal scaling of the lophophore filter-pump in ectoprocts (Bryozoa) excludes physiological regulation of filtration rate to nutritional needs. Test of hypothesis. Mar Ecol Prog Ser 156:109-120

Riisgård HU, Larsen P (1996) Filter-feeding in marine macroinvertebrates: pump characteristics, modelling and energy cost. Biol Rev 70:67-106

Riisgård HU, Larsen. PS, Nielsen NF (1996) Particle capture in the mussel Myrtilus edulis the role nf latero-frontal cirri Mar Biol 127:259-266

Riisgård HU, Manríquez P (1997) Filter-feeding in fifteen marine ectoprocts (Bryozoa): particle capture and water pumping. Mar Ecol Prog Ser 154:223-239

Rubenstein DI, Koehl MAR (1977) The mechanisms of filter feeding: some theoretical considerations. Am Nat 111: 981-994

Rudwick MJS (1962) Filter-feeding mechanisms in some brachiopods from New Zealand. J Linn Soc Lond Zool 44: $592-615$

Ryland JS (1976) Physiology and ecology of marine bryozoans. Adv Mar Biol 14:285-443

Shimeta J, Jumars P (1991) Physical mechanisms and rates of particle capture by suspension feeders. Oceanogr Mar Biol Annu Rev 29:191-257

Silén L (1972) Fertilization in the Bryozoa. Ophelia 10:27-34

Silverman H, Lynn JW, Dietz TH (1996) Particle capture by the gills of Dreissena polymorpha: structure and function of latero-frontal cirri. Biol Bull (Woods Hole) 191:42-54

Silvester NR (1988) Hydrodynamics of flow in Mytilus gills. J Exp Mar Biol Ecol 120:171-182

Sleigh MA, Aiello E (1972) The movement of water by cilia. Acta Protozool 11:265-277

Smith LW (1973) Ultrastructure of the tentacles of Flustrellidra hispida (Fabricius). In: Larwood GP (ed) Living and fossil Bryozoa. Academic Press, London, p 335-342

Strathmann RR (1971) The feeding behavior of planktotrophic echinoderm larvae: mechanisms requlation and rates of suspension feeding. J Exp Mar Biol Ecol 6:109-160

Strathmann R (1973) Function of lateral cilia in suspension feeding lophophorates (Brachiopoda, Phoronida, Ectoprocta). Mar Biol 23:129-136

Strathmann RR (1982) Cinefilms of particle capture by an 
induced local change of beat of lateral cilia of a bryozoan. J Exp Mar Biol Ecol 62:225-236

Strathmann RR, Bonar D (1976) Ciliary feeding of tornaria larvae of Ptychodera flava (Hemichordata: Enteropneusta). Mar Biol 34:317-324

Strathmann RR, Jahn TL, Fonseca RC (1972) Suspension feeding by marine invertebrate larvae: clearance of particles by ciliated bands of a rotifer, pluteus, and trochophore. Biol Bull (Woods Hole) 142:505-519

Editorial responsibility: Tom Fenchel (Contributing Editor), Helsinger, Denmark
Strathmann RR, McEdward L (1986) Cyphonautes' ciliary sieve breaks a biological rule of inference. Biol Bull (Woods Hole) 171:694-700

Vogel S (1994) Life in moving fluids. Princeton University Press, Princeton, NJ

Wildish D, Kristmanson D (1997) Benthic suspension feeders and flow. Cambridge University Press, Cambridge

Winston JE (1978) Polypide morphology and feeding behavior in marine ectoprocts. Bull Mar Sci 28:1-31

Submitted: February 16, 1998; Accepted: April 6. 1998 Proofs received from author(s): June 8, 1998 